\title{
A Speculative Efficiency Analysis of the London Metal Exchange in a Multi-Contract Framework
}

\author{
Sascha Otto \\ Helmut-Schmidt-Universität, Institut für Internationale Finanzierung \\ Holstenhofweg 85, 22043 Hamburg, Germany \\ Tel:49-40-1888-6263 E-mail: sascha.otto@gmx.com
}

\begin{abstract}
We analyze the speculative efficiency of the six base metals traded at the London Metal Exchange (LME) for the post-Tin Crisis period from 1991-2008. Especially the influence of different futures contracts on the one side and different underlyings on the other side provides economic insights for market participants like hedgers and speculators. We focus on the 3-month and 15-month futures contracts for all six base metals and conduct single-contract test for every base metal applying an ARMA process. This system is expanded to the multi-contract case, modeling the forecast error as an ARMAX process, where we analyse the interaction of 3-months and a 15-month futures contracts for a single market and the interaction of all six base metals. We find a strong influence of the 3-month futures contract on the 15-month futures contracts. Market participants trading the 15-month contracts should therefore consider the information provided by the 3-month futures contracts.
\end{abstract}

Keywords: London Metal Exchange, LME, Speculative Efficiency, Futures markets, Commodities

JEL classification: G14, G15, Q30

\section{Introduction}

The efficient market hypothesis (EMH) has been tested extensively on different stock, commodity and currency markets and their derivatives. A market is said to be efficient if the market prices fully reflect all currently available information [Fama (1970)]. The efficiency of a market is of strong interest, as market participants can trade on efficient markets without extensive and expensive information research. The EMH is a joint hypothesis composed of the thesis that market participants form their expectations based on the rational expectations hypothesis and have the opinion that the equilibrium process generates no excess returns.

Commodity markets are mainly based on the coexistence of spot and futures contracts with different maturities. A spot contract obliges the buyer and the seller to fulfil their commitments immediately. In contrast, a futures contract obliges both parties to fulfil their contractual commitment at a stipulated future prompt date. The difference between the actual spot and futures price reflects the expectation of market participants, benefit of consuming the commodity immediately and expenses for warehousing and insurance. One way to test the EMH for futures markets has been the hypothesis that the futures price $F_{t, n}$ is the best unbiased predictor of the future spot price $S_{t+n}$ [i.e. Hansen and Hodrick (1980) and King (2001)]. The forecast error $e_{t, n}=S_{t+n}-F_{t, n}$ has zero mean and is serially uncorrelated under the null hypothesis that the EMH is true.

Bilson (1981) shows that best unbiased forecasting using the forward price is not a necessary component of either rational expectations or an efficient markets approach by constructing examples of markets in which market expectations are rational but in which futures prices are not equal to the future spot price because of transaction cost and risk aversion. Furthermore, he presents the possibility of constructing a framework in which markets are efficient in the sense of removing any opportunity for riskless excess returns but which are predictably biased in the futures price forecast. We join Bilson in clarification of the unbiased predictor hypothesis as the speculative efficiency hypothesis.

As Canarela and Pollard (1986) show one possible way to empirically test the speculative efficiency hypothesis with overlapping data is the application of an autoregressive moving average (ARMA) process for the forecast error term. We analyze the speculative efficiency of the six industrially used non-ferrous base metals copper, aluminium, zinc, nickel, lead and tin traded at the London Metal Exchange (LME) in a multi-contract framework for the post-Tin Crisis period of 1991-2008.

There has been some research on the LME for the base metals copper, lead, tin and zinc but the markets for aluminium and nickel have so far mostly been neglected. In addition, the majority of studies focus on the pre-Tin Crisis period [e.g. Goss (1985)]. As the Tin Crisis in 1986 nearly caused the collapse of the LME and led to the complete restructuring of the LME rulebook and trading regulations, a revision of former results is useful and necessary. Furthermore, all studies have only analyzed the most liquid 3-month futures contract, although there are other contracts, e.g. the 15-month futures contract. The second section explains the general function and characteristics of the LME in comparison with other commodities futures markets. The literature on commodity futures market efficiency with emphasis on the base metals is reviewed in Section 3. We demonstrate the applied 
statistical model selection and specification in Section 4. Our objective is the analysis of dependencies between the six base metal markets and futures contracts with different maturities. We use three different test settings for our analysis. We conduct a single-market and single-contract test for the 3-month as well as the 15-month futures of all six base metals, where the forecast error is based on an ARMA process. This system is expanded to the multi-contract case, modeling the forecast error as an ARMA with a distributed-lag (ARMAX) process. We first analyze the interaction of 3-month and 15-month futures contracts for a single market. Finally, the interaction of all six base metals using the 3-month and 15-month futures contracts in a multi-contract and multi-market test will be analyzed. We also compare our findings to these of other studies analyzing the pre-Tin Crisis period and using different methodologies. We finalize the paper with a discussion of our results in Section 5.

\section{General Function and Characteristics of the LME}

The LME, founded in 1877, is the world's oldest metallurgical exchange. It is the most liquid non-ferrous base metal exchange, with a trading volume of $\$ 7.41$ billion in 2009. It offers a 24hour trade by a three-stage system of open outcry during four "ring" sessions, where every single metal is traded for a five-minute period, the "LME Select" electronic platform and the "Inter-office" telephone market. There are three primary functions performed by the LME. First, a hedging facility against price fluctuations in world base metal markets is provided. Second, settlement prices determined by the LME price committee are used internationally as a valuation reference for any base metal-related activity. Third, a warrant-based storage and physical delivery system allows markets participant to directly trade approved base metal brands. It provides cash, futures and option contracts for the six base metals with prompts up to 123 months forward. Furthermore, the LME has introduced futures contracts on aluminum alloys for the automotive industry, plastic (both polypropylene and polyethylene) and steel billets. Contracts for the minor metals cobalt and molybdenum will be introduced in 2010.

The most liquid and most important contract of all underlyings is the daily rolling 3-month futures contract. Unlike other commodity markets, which are usually based on monthly prompt dates, LME futures contracts run on a daily basis for a period of three months. The use of daily prompt dates is an important difference between the LME and other futures exchanges (e.g., the New York Mercantile Exchange and the Shanghai Metal Exchange). Within the rolling three-month period, every weekday can be traded as a prompt date. After the three-month period, daily prompts for forward trading are reduced to weekly prompts for a period of up to six months and the reduced to monthly prompt dates. Furthermore, most LME brokers provide the ability to trade non-LME prompt dates via OTC contracts.

The most important trading session is the second ring session. At the end of this trading session the LME price committee determines the official daily settlement price for the cash contracts and for the 3-months, 15-months and 27-months futures. (Note 1) For our analysis, the settlement prices will be used. Brokers also offer a hedging technique called pricings, which provides market participants the ability to trade on the basis of monthly average prices. Therefore a market participant predetermines the settlement month and the quantity of futures. The futures are settled on the basis of the monthly average settlement price (MASP) at the end of the predetermined period. These pricings permit the use of average monthly prices in our analysis, as these average prices are actually tradable for a predetermined month.

Another important distinction from other futures exchanges is the physical delivery of all traded base metals based on a warrant system. The warrants are issued by LME-approved warehouses. Cash settlement of due contracts, as provided by other futures exchanges, is not possible. The system can be interpreted as a major concession to physical metal traders rather than as one to financial investors.

When a delivery date falls due, the LME price will naturally converge with the spot price. In reality, physical delivery occurs only in a very small percentage of less than $1 \%$ for base metal contracts, as most market participants use the exchange for hedging purposes and close open futures contracts before they fall due [Crabbe (1998)].

As the LME does not oblige members to clear the contracts with LCH.Clearnet, the LME's clearinghouse, the LME should be considered a "principal-to-principal" market. (Note 2) Gilbert (1986) has therefore argued that the LME should not be regarded as a futures market but as an organized forward market that performs many of the functions of a futures market.

\section{Literature Review}

As pointed out by Samuelson (1965) and Fama (1970) independently, a financial market can be considered efficient if prices fully reflect all available information. The agents form their expectations rationally, and any possible excess returns will be arbitraged away. Most studies focusing on the efficiency of futures markets appeal either to the unbiasedness hypothesis by Hansen and Hodrick (1980) or to the speculative efficiency hypothesis by Bilson (1981). The main idea of both approaches is the hypothesis that the futures price is the best unbiased predictor of the future spot price. If economic agents are risk neutral, the costs of transaction are zero, information is used rationally, and the market is competitive, the market will be efficient in the sense that the expected rate of return to speculation in the futures market will be zero. Fama (1991) points out that market efficiency involves testing a joint hypothesis of efficiency and the asset pricing model, in this case the analysis of the joint hypothesis of market efficiency and unbiasedness in futures prices. 
There are some studies that focus on the LME. Taylor (1980) tests the random walk hypothesis on spot prices for copper for the period 1966-1978 and for zinc, lead and tin for the period 1970-1978. His results reject the random walk hypothesis for all base metals but tin. Goss (1981) analyzes the relationship between futures and spot prices for the copper, zinc, lead and tin markets for the period 1971-1978. His results show a bias in the futures prices for lead and tin. Bird (1985) uses filter techniques to test for the weak-form efficiency of the LME prices for the same metals for the period 1972-1982. His results showed evidence of market inefficiency for copper, lead and zinc and no evidence for tin. Goss (1985) applies a joint test for the same metals for the sample period of 1966-1984. His results could reject the EMH for copper and zinc, but failed to reject the EMH for lead and tin. Canarella and Pollard (1986) test the hypothesis that the futures price is an unbiased predictor of the future spot price using both overlapping and non-overlapping data for copper, lead, tin and zinc contracts covering the period 1975-1983. Using three different estimation methods, they confirm the speculative efficiency hypothesis. MacDonald and Taylor (1988) test for cointegration for four metals in the LME for the period of 1976-1987. They conclude that the copper and lead futures markets can be considered efficient but reject the EMH for tin and zinc. Gross (1988) examines unvaried LME prices on the mean square error criterion for the period of 1983-84 in order to test the semi-strong EMH for copper and aluminium futures. He provides evidence that the semi-strong EMH cannot be rejected for both base metals. Moore and Cullen (1995) analyze the proposition that forward rates are unbiased predictors of future spot rates for base metal prices on the LME for all six base metals between 1985 and 1989 in a single-market and single-contract framework. They showed that the possibility of long-run speculative efficiency cannot be rejected. Lucey (2003) examines the daily seasonal patterns in the returns of aluminium, copper, zinc, lead and nickel for the period of 1989-2002. His results indicate the existence of daily seasonality, particularly Monday and Thursday returns. Kenourgios and Samitas (2004) analyze the LME copper futures contracts with 3-month and 15-month maturities for the period of 1989-2000. He tests for both long-run and short-run efficiency using cointegration and an error correction model. His results suggest that copper futures market is inefficient.

In summary, there has not been consensus about the efficiency of the LME. One reason for the heterogeneous results are the different test setups. In particular, some of the pre-Tin Crisis studies have been criticized for using incorrect econometric methodology. (Note 3) Moreover all studies have analyzed the LME from a single-market perspective, whereas a multi-market perspective should be the natural choice, as producers of base metals, physical metal traders and even financial investors take the economic interrelation of the base metals into account when making trading decisions. (Note 4) Furthermore all of the studies, with the exception of Kenourgios and Samitas (2004), focus only on the 3-month daily rolling futures contract; other futures contracts are not considered.

\section{Statistical Methodology}

As discussed, speculative efficiency hypothesis implies under the condition of risk neutrality and zero transaction cost

$S_{t+n}=F_{t, n}+e_{t, n}$

Equation (1) outlines that the futures price $F_{t, n}$ with maturity in $n$ periods quoted at a point in time $t$ is the best unbiased predictor of the future spot price $S_{t+n}$, when the futures contract falls due, given the information framework available at point in time $t$ and given that the forecast error term $e_{t}$ has zero mean and is serially uncorrelated. We will base our analysis on this basic pricing model. Furthermore, we take the random and unpredictable appearance of new information in an efficient market into consideration. Accordingly, there is no methodical relationship between the present and any previous forecast error of the own or other base metals. These implications for speculative efficiency can be written as

$E\left(S_{t+n}-F_{t, n} \mid S_{t}-F_{t-n, n}\right)=0$

At first, we analyze the six base metals considering the 3-month and 15-month futures contracts in a single-market context. Our sample database consists of the monthly average second-ring prices as published by the LME for the cash and futures contracts for the period between July 1991 to March 2008. There has been some discussion in the literature regarding the EMH in futures markets, that using averaged data may result in spurious conclusions [e.g., Gilbert (1986), Gross (1988)]. The main argument against testing EMH on averaged data is the synthetic character. Under normal circumstances, it is not possible to use averaged data as an underlying basis for futures trading, and argumentation based on this database proves nothing, due to the lack of arbitrage possibilities required for the speculative efficiency. This argument is correct for most futures exchanges, as they do not provide pricings, instruments with which to trade futures on the basis of an average price for a predetermined period. The LME offers the trading on basis of the monthly average settlement price (MASP). Market participants can predetermine a settlement month and quantity of futures. At the end of the period, the future contracts are settled on basis of the MASP. Therefore the application of averaged data for our analysis is feasible. Using the methodology of Canarella and Pollard (1986), we consider three models: 


$$
\begin{aligned}
& s_{t+n}-f_{t, n}=e_{t, n} \\
& s_{t+n}-f_{t, n}=a_{0}+e_{t, n} \\
& s_{t+n}-f_{t, n}=a_{0}+a_{1}\left(s_{t}-f_{t-n, n}\right)+a_{2}\left(s_{t-1}-f_{t-n-1, n}\right)+a_{3}\left(s_{t-2}-f_{t-n-2, n}\right) \\
& +a_{4}\left(s_{t-3}-f_{t-n-3, n}\right)+e_{t, n}
\end{aligned}
$$

where $S_{t+n}$ is the natural logarithm of the spot price $S_{t+n}$ and $f_{t, n}$ is the natural logarithm of the futures price $F_{t, n}$.

As Hodrick (1987) points out, ordinary least squares (OLS) is not a valid estimation approach, due to the existence of a lagged dependent variable in Equation (4). Furthermore, if the database consists of overlapping data $(n>1)$, the forecast error follows a moving average process of order $(n-1)$ [Hansen and Hodrick (1980), Hsieh and Kulatilaka (1982)]. The moving average process is generated by the inflow of new information during the futures contract life cycle. As OLS would bias the estimated standard errors downwards and induce incorrect results regarding speculative efficiency, one approach is the utilization of non-overlapping data. We discard this approach because the analysis of the long-term 15-month futures contract reduces our sample to a featureless level.

We favor a procedure, such as the ARMA approach, that accounts for the existence of the moving average process for the forecast error term; we reason that, by not taking into account the MA structure, participants use future information, that they do not have access to, when making their decisions.

All parameters are computed by maximum-likelihood estimation. Diagnostic checking of the appropriateness of these models is undertaken in two ways. First, we check all forecast error time series for stationarity using the Augmented Dickey-Fuller (ADF)-test and KPSS-test. We failed to reject the null hypothesis of stationarity for all times series. Second, we check the constraint of white noise of the residuals by implementing the Ljung-Box test with Q-levels of 12 and 24 lags on the 3-month futures contact and 24 and 48 lags on the 15 -month contract. We failed to reject the white-noise null hypothesis for all residual time series. As demonstrated by Galbraith and Galbraith (1974), we also consider the standard errors of the moving average coefficients. These should be of the same magnitude for a well-specified model. This condition is satisfied by all models in consideration of the quantity of parameters.

The single-market analysis is performed using the Wald test and the likelihood ratio test. The Wald test is used to test whether an independent variable has a statistically significant relationship with a dependent variable [Wald (1943)]. The test statistic used for testing the speculative efficiency is:

$$
F=\frac{\left(\tilde{u}^{\prime} \tilde{u}-u^{\prime} u\right) / q}{\tilde{u}^{\prime} \tilde{u} / N-k}
$$

where $\widetilde{u}^{\prime} \tilde{u}$ is the restricted sum of squared residuals, $u^{\prime} u$ is the unrestricted sum of squared residuals, $q$ is the number of restrictions implied, $N$ is the number of observations and $k$ is the total unrestricted number of parameters. F will be central $F(q, N-K)$ distributed [Cameron and Trivedi (2005)]. The Wald test has been extensively analyzed for it's suitability for ARMA processes and is widely accepted. [e.g., Galbraith and Zinde-Walsh (1997)].

Speculative efficiency implies that none of the right-hand side terms of the three models contains any explanatory power; we thus test three hypotheses using the Wald test, where $\mathrm{H}_{1}$ is related to equation (3) and $\mathrm{H}_{2}$ and $\mathrm{H}_{3}$ are related to equation (4):

$$
\begin{aligned}
& H_{1}: a_{0}=0 \\
& H_{2}: a_{1}=a_{2}=a_{3}=a_{4}=0 \\
& H_{3}: a_{0}=a_{1}=a_{2}=a_{3}=a_{4}=0
\end{aligned}
$$

We also test $H_{3}$ by means of a likelihood ratio test of the form $L R=-2 \log \frac{L r}{L u}$, where $L r$ is the maximum value of the restricted likelihood function. In this case, the forecast error follows only an MA procedure of order $(n-1)$, and $L u$ is the maximum value of the unrestricted likelihood function. The likelihood ratio test statistic $L R$ follows a chi-square distribution with a degree of freedoms equal to the number of restrictions. With these tests, two dimensions are tested simultaneously. The first dimension is the unbiased prediction hypothesis. Furthermore it is a test of the degree that the forecast errors can be explained by the covariates. Next, we expand our framework to a multi-contract framework. We therefore extend our model to the ARMAX specification and include the forecast 
error $e_{i j}=\left(s_{t}^{i j}-f_{t-n, n}^{i j}\right)$ of the 3-month futures contract's corresponding 15-month contract for the underlying base metal and vice-versa. Due to trading usances, brokers normally calculate the futures prices based on the most liquid 3-month futures contract. The futures contract is then either adjusted by carry trades or settled with other open contracts on the broker's trading card. Thus we expect influence of the corresponding futures contracts and expand out model:

$$
\begin{aligned}
& s_{t+n}-f_{t, n}=a_{0}+a_{1}\left(s_{t}-f_{t-n, n}\right)+a_{2}\left(s_{t-1}-f_{t-n-1, n}\right)+a_{3}\left(s_{t-2}-f_{t-n-2, n}\right) \\
& +a_{4}\left(s_{t-3}-f_{t-n-3, n}\right)+b_{i j}\left(s_{t}^{i j}-f_{t-n, n}^{i j}\right)+e_{t, n}
\end{aligned}
$$

where $s_{t}^{i j}$ is the natural logarithm of the spot price $S_{t+n}^{i j}, f_{t-n, n}^{i j}$ is the natural logarithm of the futures price $F_{t, n}^{i j}, i$ is the underlying parameter where 1 is aluminum $(\mathrm{Al}), 2$ is copper $(\mathrm{Cu}), 3$ is nickel $(\mathrm{Ni}), 4$ is lead $(\mathrm{Pb}), 5$ is tin $(\mathrm{Sn})$ and 6 is zinc $(\mathrm{Zn})$ and $\mathrm{j}$ is the contract parameter where 1 is the 3 -month futures contract and 2 is the 15 -month futures contract.

We check the hypothesis using the Wald as well as the likelihood ratio test:

$$
H_{4}: a_{0}=a_{1}=a_{2}=a_{3}=a_{4}=b_{i j}=0
$$

Finally we expand our framework to a multi-market and multi-contract framework. These additional covariates might contain additional information due to three facts. First the base metals can substitute each other for some production processes. Second, most mines contain more than one base metal and metal producing companies take different base metal prices into account for extraction processes. Third, trading companies and brokers normally trade all base metals simultaneously in the same department and trading desk. Hence trading decisions are normally based on a comprehensive market analysis of all base metals. Therefore we analyze the model

$$
\begin{aligned}
& s_{t+n}-f_{t, n}=a_{0}+a_{1}\left(s_{t}-f_{t-n, n}\right)+a_{2}\left(s_{t-1}-f_{t-n-1, n}\right)+a_{3}\left(s_{t-2}-f_{t-n-2, n}\right)+a_{4}\left(s_{t-3}-f_{t-n-3, n}\right) \\
& +\sum_{i=1}^{6} \sum_{j=1}^{2} b_{i j}\left(s_{t}^{i j}-f_{t-n, n}^{i j}\right)+e_{t, n}
\end{aligned}
$$

As the $b_{i j}$ terms only consist of the exogenous forecast errors of the other base metals, we exclude the endogenous forecast error, already considered for $a_{1}$. We check the hypothesis using the Wald and the likelihood ratio test:

$$
H_{5}: a_{0}=a_{1}=a_{2}=a_{3}=a_{4}=b_{11}=b_{12}=b_{21}=\ldots=b_{62}=0
$$

By reason of the multitude of parameters considered, we focus on the likelihood ratio tests. As robustness check, we also rerun all Wald and likelihood-ratio tests using winsorized data with cut-off points at the 1st and 99th percentile to avoid the effect of outliers. Furthermore we analyze the development of speculative efficiency using two subperiods before and after 2000, which roughly coincide with, first, the bull market in equities and weak commodity prices in the 1990s and, second, the period of relatively greater commodity strength after 2000 .

\section{Empirical Results}

The tables present the results for the different test settings. Tables 1 to 6 present the model's coefficients, standard errors, and Ljung-Box Q-Statistics and the results for the Wald test setups $H_{1}$ to $H_{4}$ for the 3-month contracts. Tables 7 to 12 contain the 15 -month contracts. The multi-market analysis is presented in Tables 13 . The results of the likelihood ratio test are demonstrated in Table 14.

Furthermore test result using winsorized data with cut-off points at the 1st and 99th percentile are presented in Table 15. Test results for the two subperiods before and after 2000 are demonstrated in Table 16.

The first hypothesis proposes the basic statement of the speculative efficiency, that the futures price is the best predictor of the future spot price. Other information, such as the past forecast error, is not considered. We failed to reject the null hypothesis for all forecast errors based on the 3-month futures contracts at a $5 \%$ level of significance. These findings coincide with former studies [e.g., Canarella and Pollard (1986), Moore and Cullen (1995)]. For the 15-month contracts, we failed to reject the null hypothesis for all base metals except for lead and tin. Interestingly Goss (1981) notices the same bias for both metals for the period of 1971-1978 when analyzing the forecast error of the 3-month contract. A possible explanation might be the fact that the contracts based on the two base metals are considered to be illiquid. (Note 5) As the concept of speculative efficiency implies the principles of arbitrage, sufficient liquidity is required for market efficiency.

$\mathrm{H}_{2}$ focuses only on past forecast errors. For the 3-month contracts, we failed to reject the null hypothesis for all but tin and for the 15-month contracts for all but aluminium, tin and zinc. 
Regarding $\mathrm{H}_{3}$, we analyze the present and past forecast errors. As shown by Agresti (2007), likelihood ratio tests are more reliable with small samples and an increasing number of parameters than the Wald test. We put our main focus on the results of the likelihood ratio tests, which are mainly confirmed by the results of the Wald test. We reject the null hypothesis only for the 3-month contracts of copper and zinc, and for the 15-month contracts of lead and tin. These findings support the results of Goss (1985), Kenourgios and Samitas (2004).

By extending our analysis to the multi-contract framework, we cannot find any additional explanatory power for the 3 -month contracts by adding 15-months forecast error to the models. Our findings regarding speculative efficiency for all six base metals remain unchanged. Inversely, the 3-month forecast errors add explanatory power to models based on the 15-month contract. In addition to tin, which had already been rejected in the single-contract framework, we reject the null hypothesis of speculative efficiency for the 15-month contracts of copper, nickel and zinc based on the results of the likelihood ratio test.

By adding the forecast error of the corresponding 3-month contracts to the framework, we reject the speculative hypothesis for the three base metals. These findings are indeed contrary to the results of existing EMH studies of the LME, which only focus on 3-month contracts. A possible explanation for the one-way influence of the 3-month forecast error on the 15-month contract might be the business practices of most LME brokers and speculators to trade all futures contract maturities on the basis of the 3-month futures contract and to either adjust the underlying contract by carry trades or take the risk of a shifting forward curve. Another explanation might be the shift of trading volume to the exchange's electronic trading platform, LME Select. In spite of the possibility of trading all maturities for all underlyings on LME Select, only the spot and 3-month futures contracts are considered to be liquid and actively traded. Therefore market participants using LME Select have to adjust their contracts to the appropriate prompt date via carry trades. Among the supply and demand of carry trades, the borrowing or lending rates of the "3's to maturity" carry trades are affected by past forecast errors. Furthermore, as many risk-controlling systems take the past forecast errors for the calculation of the Value-at-Risk into account, LME brokers have to consider these figures for managing the maturity structure of their trading cards.

The extension of our analysis to the multi-contract and multi-market framework results in the additional rejection of the null hypothesis for the 3-month futures contracts of nickel and tin. As demonstrated for tin, we have already found some explanatory power for the past forecast error of the same contract using the Wald test but have found none for the present. These findings were not supported by the likelihood ratio test under the single-market and multi-contract framework, but they were under the multi-market framework. As a robust check, winsorized data with cut-off points at the 1st and 99th percentile has been analyzed. In most instances, the avoidance of outliers does not influence the test results. Regarding the likelihood ratio tests winsorized data rejects additionally $\mathrm{H}(3)$ and $\mathrm{H}(4)$ for the 3-month nickel contract. In general, winsorization biases our findings to rejection of the null hypotheses of speculative efficiency. In addition to the complete sample period, we analyze the two subperiods before and after 2000. Especially for the period after 2000, we find a broad-based reduction of speculative efficiency in comparison to the pre-2000 period. In particular, speculative efficiency reduced significantly for both copper and nickel contracts and the 15-month contract of lead and zinc. A reason for the decline of speculative efficiency might be the increasing activity of speculative investors like hedge funds in commodity markets after the burst of the dotcom bubble in 2000 .

In summary, we reject the null hypothesis of speculative efficiency for all base metals except for both aluminum and the 3-month lead contract in a multi-contract, multi-market framework. In particular, the additional analysis of the corresponding contract for the same base metal added explanatory power to the analysis. The consideration of other base metals also added informative value to the speculative efficiency analysis, a fact that has so far been neglected by studies concerning the LME. A reason for the efficiency of the aluminum contracts might that it has become the most liquid contract of the LME. Moreover, the price of aluminum became, in addition to copper, a leading economical indicator for the commodities markets, which also attracted speculators such as hedge funds and commodity trading advisors (CTA).

From an academic point of view, the test for speculative efficiency of the LME is especially interesting in reference to the efficient-market hypothesis. As we reject the speculative efficiency hypothesis for all base metals except for both aluminum and the 3-month lead contracts, the futures prices do not fully reflect all available information. Hence these results rebut the original efficient-market hypothesis by Fama for base metal commodity markets and should be an interesting contribution to the general discussion of market efficiency and behavioural finance. Further studies regarding market efficiency of base metals should focus on the different interaction of futures contracts of different commodities markets, such as the New York Mercantile Exchange and the Shanghai Metal Exchange. Moreover, studies analysing the information content of key data, such as warehouse stocks and open interest, might be especially enlightening.

Furthermore, these findings should be especially of interest for hedgers, speculators and market regulators. Hedgers use the LME futures contracts to offset exposure to price fluctuations of an underlying physical metal contract, to minimise the unwanted price risk. Principally, hedgers are interested in an efficient market because prices always fully reflect available information. In the case of market-efficiency, hedgers do not have to analyze market data for their 
hedging decisions. Therefore, aluminum can be hedged efficiently without an expensive market analysis. For the other base metals, hedgers should take the additional price-generating influence of futures contracts with different maturities into account to optimise their hedging strategies.

Speculators try to generate excess returns by forecasting base metal prices and take a corresponding futures position. Most forecasting systems are based on market inefficiencies and speculators analyze market data to establish excess, generating trading strategies. As speculative efficiency hypothesis is not appropriate for all base metals, there might be some opportunities for speculators to generate excess returns. Further studies should test if these inefficiencies can be used for real-life trading strategies.

Market regulators observe base metal futures prices in order to find evidence of market manipulation and insider trading. An inefficient market complicates the monitoring because regulators cannot verify precisely the occurrence of market manipulation, as any market anomaly might be based on the market inefficiency. As speculative efficiency hypothesis can be rejected for all base metals except aluminum, the monitoring of market manipulation and insider trading need sophisticated models to take the interaction of different futures contracts into account.

\section{Summary and Conclusion}

We analyzed the speculative efficiency of six base metals traded at the LME using the 3-month and 15-month futures contracts. We focused on the influence of the present and past forecast error of these futures as well as corresponding futures with different maturities. We extended our analysis to the multi-market framework and implemented the forecast errors of the other base metals in our analysis for speculative efficiency.

In contrast to former studies regarding the LME, we reject the speculative efficiency hypothesis for all base metal contracts except for both aluminum and the 3-month lead contract. Furthermore, speculative efficiency reduces significantly for the period after 2000 . The main reason for this discrepancy might be the fact that all relevant studies have only focused on the 3-month futures contract. Furthermore, none of the studies applies the possibility of trading monthly averaged prices via the LME's pricings. As nearly all of the studies have used the pre-Tin Crisis period as sample basis, another reason might be a change in market efficiency following the Tin Crisis.

We see the main reasons for efficiency in the aluminum market in the high level of liquidity, the outstanding general economic importance and the increased activity of speculative traders. Our main conclusion is that hedgers, traders and market regulators should take the influence of different contracts for the same underlying and their interaction into account. In particular, the liquid and generally accepted LME 3-month contract added explanatory power to the 15-month contract. However, the rest of the base metal markets also have an impact on the price-generating process of the underlying futures contract. Therefore, potential interactions between different commodities, due to trading usances or other economic reasons, should be considered when analyzing market efficiency. Furthermore, efficient hedging strategies should also include any given interaction between different contracts and markets.

\section{References}

Agresti, A. (2007). An introduction to categorical data analysis, New York.

Bilson, J.F.O. (1981). The 'Speculative Efficiency' Hypothesis. Journal of Business, Vol. 51, pp. 435-451.

Bird, P. J.W.N. (1985). The Weak Form Efficiency of the London Metal Exchange. Applied Economics, Vol. 17, pp. 571-581.

Cameron, A.C. and Trivedi P. K. (2005). Microeconometrics: methods and applications. Cambridge.

Canarella, G. and Pollard, S.K. (1986). The Efficiency of the London Metal Exchange. Journal of Banking and Finance, Vol. 10, pp. 573-593.

Crabbe, P. (1999). Metals Trading Handbook: a market companion for users of the London Metal Exchange. Cambridge.

Fama, E. F. (1970). Efficient Capital Markets: A Review of Theory and Empirical Work. Journal of Finance, Vol. 25, pp. 383-417.

Fama, E. (1991). Efficient Capital Markets: II. Journal of Finance, Vol. 46, pp. 1575-1617.

Galbraith, R.F. and Galbraith, J.I. (1974). On the inverses of some patterned matricies arising in the theory of stationary time series. Journal of Applied Probability, Vol. 11, pp. 63-71.

Galbraith, J.W. and Zinde-Walsh, V. (1997). On some simple, autoregression-based estimation and identification techniques for ARMA models. Biometrika, Vol. 84(3), pp. 685-696.

Gilbert, C.L. (1986). Testing the efficient markets hypothesis on averaged data. Applied Economics, Vol. 18, pp. 1149-1166.

Goss, B.A. (1981). The Forward Pricing Function of the London Metal Exchange. Applied Economics, Vol.13, pp. 133-150.

Goss, B.A. (1985). The Forward Pricing Function of the London Metal Exchange. In B.A. Goss: Futures Markets: Their Establishment and Performance, London, pp. 157-73. 
Gross, M. (1988). A Semi Strong Test of the Efficiency of the Al and Cu markets at the LME. Journal of Futures Markets, Vol. 8(1), pp. 67-77.

Hansen, L.P. and Hodrick, R.J. (1980). Forward Exchange Rates as optimal Predictors of Spot Rates: An Econometric Anlaysis. Journal of Political Economy, Vol. 88, pp. 829-853.

Hodrick, R.J. (1987). The Empirical Evidence of Forward and Futures Foreign Exchange Markets, Harwood.

Kenourgios, D. and Samitas, A. (2004). Testing Efficiency of the Copper Futures Market: New Evidence from London Metal Exchange. Global Business and Economics Review Anthology, pp. 261-271.

King, J. (2001). Testing the Efficient Markets Hypothesis with Futures Markets Data: Forecast Errors, Model Predictions and Live Cattle. Australian Economic Papers, Vol. 40, pp. 581-585.

Lucey, B.M. (2003). Daily Seasonality in LME Base Metal Returns 1989-2002: A Robust Analysis. Working Paper [Online], http://ssrn.com/abstract=368301 (August 1, 2010).

MacDonald, R. and Taylor, M.P. (1988). Metal Prices, Efficiency and Cointegration: Some Evidence from the LME. Bulletin of Economic Research, Vol. 40, pp. 235-239.

Moore, M.S. and Cullen, U. (1995). Speculative Efficiency on the London Metal Exchange. The Manchester School, Vol. 63, pp. 235-56.

Samuelson, P. (1965). Proof that properly anticipated prices fluctuate randomly. Industrial Management Review, Vol. 6, pp. 41-49.

Taylor, S.J. (1980). Conjectured Models for Trends in Financial Prices, Tests and Forecasts. Journal of the Royal Statistic Society, Vol. 143, pp. 338-362.

Wald, A. (1943). Tests of Statistical Hypotheses Concerning Several Parameters When the Number of Observations is Large. Transactions of the American Mathematical Society, Vol. 54, pp. 426-482.

\section{Notes}

Note 1 . Tin contracts can only be traded with prompt dates up to 15 -months.

Note 2. The Tin Crisis and the collapse of the International Tin agreement could have been prevented, if the LME had been cleared in the manner of a standard futures market.

Note 3. For example, Gilbert (1986) criticizes Goss (1981) for using non-tradable monthly averaged data.

Note 4. To quote an example, zinc mines also contain some amount of lead, and copper mines also contain some amount of tin.

Note 5. The 10-year average open interest was about 18.600 lots for tin and about 54.000 lots for lead. By comparison, copper showed number of 208.000 lots, and aluminium showed about 416.000 lots

Table 1. 3-month aluminium futures

\begin{tabular}{|c|c|c|c|c|}
\hline & Equation 2 & Equation 3 & Equation 4 & Equation 6 \\
\hline \multirow[t]{2}{*}{$\mathrm{a} 0$} & & 0.0020 & 0.0027 & 0.0035 \\
\hline & & $(0.0096)$ & $(0.0101)$ & $(0.0102)$ \\
\hline \multirow[t]{2}{*}{ a1 } & & & 0.1034 & 0.1418 \\
\hline & & & $(0.1073)$ & $(0.1154)$ \\
\hline \multirow[t]{2}{*}{$\mathrm{a} 2$} & & & -0.0853 & -0.0772 \\
\hline & & & $(0.095)$ & $(0.0952)$ \\
\hline \multirow[t]{2}{*}{ a3 } & & & 0.0423 & 0.0474 \\
\hline & & & $(0.0912)$ & $(0.0912)$ \\
\hline \multirow[t]{2}{*}{ a4 } & & & 0.1354 & 0.1685 \\
\hline & & & $(0.0909)$ & $(0.0986)$ \\
\hline \multirow[t]{2}{*}{ Al15 } & & & & -0.0449 \\
\hline & & & & $(0.0552)$ \\
\hline \multirow[t]{2}{*}{$\mathrm{Q}(12)$} & 8.0609 & 8.0625 & 5.6420 & 6.7511 \\
\hline & {$[0.623]$} & {$[0.623]$} & {$[0.844]$} & [0.749] \\
\hline \multirow[t]{2}{*}{$\mathrm{Q}(24)$} & 14.2320 & 14.2350 & 10.8280 & 11.0660 \\
\hline & [0.893] & [0.893] & [0.977] & {$[0.974]$} \\
\hline $\mathrm{R}^{2}$ & 0.6586 & 0.6587 & 0.6656 & 0.6670 \\
\hline \multicolumn{3}{|c|}{$\mathrm{H}(1): \mathrm{a} 0=0$} & $\mathrm{~F}=0.0685$ & {$[0.7938]$} \\
\hline \multicolumn{3}{|c|}{$\mathrm{H}(2): \mathrm{a} 1=\mathrm{a} 2=\mathrm{a} 3=\mathrm{a} 4=0$} & $\mathrm{~F}=0.8812$ & {$[0.4766]$} \\
\hline \multicolumn{3}{|c|}{$\mathrm{H}(3): \mathrm{a} 0=\mathrm{a} 1=\mathrm{a} 2=\mathrm{a} 3=\mathrm{a} 4=0$} & $\mathrm{~F}=0.7181$ & {$[0.6107]$} \\
\hline \multicolumn{3}{|c|}{$\mathrm{H}(4): \mathrm{a} 0=\mathrm{a} 1=\mathrm{a} 2=\mathrm{a} 3=\mathrm{a} 4=\mathrm{A} 115=0$} & $\mathrm{~F}=0.7235$ & {$[0.6312]$} \\
\hline
\end{tabular}

Table 2. 3-month copper future

\begin{tabular}{|c|c|c|c|c|}
\hline & Equation 2 & Equation 3 & Equation 4 & Equation 6 \\
\hline \multirow[t]{2}{*}{$\mathrm{a} 0$} & & 0.0240 & 0.0159 & 0.0198 \\
\hline & & $(0.0182)$ & $(0.0141)$ & $(0.0141)$ \\
\hline \multirow[t]{2}{*}{ a1 } & & & 0.1377 & 0.1884 \\
\hline & & & $(0.0830)$ & $(0.0857)$ \\
\hline \multirow[t]{2}{*}{ a2 } & & & -0.0193 & 0.0117 \\
\hline & & & $(0.08488)$ & $(0.0852)$ \\
\hline \multirow[t]{2}{*}{ a3 } & & & 0.1533 & 0.1565 \\
\hline & & & $(0.08534)$ & $(0.0838)$ \\
\hline \multirow[t]{2}{*}{$\mathrm{a} 4$} & & & 0.0675 & 0.1294 \\
\hline & & & $(0.0832)$ & $(0.0880)$ \\
\hline \multirow[t]{2}{*}{$\mathrm{Cu} 15$} & & & & -0.0658 \\
\hline & & & & $(0.0336)$ \\
\hline \multirow[t]{2}{*}{$\mathrm{Q}(12)$} & 9.7459 & 9.7170 & 6.6642 & 13.4390 \\
\hline & {$[0.371]$} & {$[0.374]$} & {$[0.672]$} & {$[0.200]$} \\
\hline \multirow[t]{2}{*}{$\mathrm{Q}(24)$} & 15.5450 & 15.4690 & 12.8410 & 23.6010 \\
\hline & {$[0.795]$} & [0.799] & {$[0.914]$} & {$[0.368]$} \\
\hline $\mathrm{R}^{2}$ & 0.7849 & 0.7871 & 0.7941 & 0.7951 \\
\hline \multicolumn{3}{|c|}{$\mathrm{H}(1): \mathrm{a} 0=0$} & $\mathrm{~F}=$ & [0.3034] \\
\hline \multicolumn{3}{|c|}{$\mathrm{H}(2): \mathrm{a} 1=\mathrm{a} 2=\mathrm{a} 3=\mathrm{a} 4=0$} & $\mathrm{~F}=2$ & [0.0664] \\
\hline \multicolumn{3}{|c|}{$\mathrm{H}(3): \mathrm{a} 0=\mathrm{a} 1=\mathrm{a} 2=\mathrm{a} 3=\mathrm{a} 4=0$} & $\mathrm{~F}=2$ & [0.0379] \\
\hline \multicolumn{3}{|c|}{$\mathrm{H}(4): \mathrm{a} 0=\mathrm{a} 1=\mathrm{a} 2=\mathrm{a} 3=\mathrm{a} 4=\mathrm{Cu} 15=0$} & $\mathrm{~F}=2$ & [0.0149] \\
\hline
\end{tabular}


Table 3. 3-month nickel futures

\begin{tabular}{|c|c|c|c|c|}
\hline & Equation 2 & Equation 3 & Equation 4 & Equation 6 \\
\hline \multirow[t]{2}{*}{$\mathrm{a} 0$} & & 0.3570 & 0.0283 & 0.0331 \\
\hline & & $(0.0224)$ & $(0.0181)$ & $(0.0185)$ \\
\hline \multirow[t]{2}{*}{ a1 } & & & 0.1535 & 0.2252 \\
\hline & & & $(0.0886)$ & $(0.1035)$ \\
\hline \multirow[t]{2}{*}{$\mathrm{a} 2$} & & & 0.0371 & 0.0185 \\
\hline & & & $(0.0918)$ & $(0.0935)$ \\
\hline \multirow[t]{2}{*}{ a3 } & & & -0.0932 & -0.03 \\
\hline & & & $(0.0900)$ & $(0.0930)$ \\
\hline \multirow[t]{2}{*}{$\mathrm{a} 4$} & & & 0.1572 & 0.2113 \\
\hline & & & $(0.0862)$ & $(0.0983)$ \\
\hline \multirow[t]{2}{*}{ Ni15 } & & & & -0.0822 \\
\hline & & & & $(0.0536)$ \\
\hline \multirow[t]{2}{*}{$\mathrm{Q}(12)$} & 10.047 & 9.9522 & 9.5718 & 11.315 \\
\hline & {$[0.436]$} & {$[0.445]$} & {$[0.479]$} & {$[0.333]$} \\
\hline \multirow[t]{2}{*}{$\mathrm{Q}(24)$} & 21.4310 & 21.2520 & 21.5630 & 20.0340 \\
\hline & {$[0.494]$} & {$[0.505]$} & {$[0.486]$} & {$[0.581]$} \\
\hline $\mathrm{R}^{2}$ & 0.7511 & 0.7548 & 0.7526 & 0.7554 \\
\hline \multicolumn{2}{|c|}{$H(1): a 0=0$} & & $\mathrm{~F}=2.4342$ & {$[0.1207]$} \\
\hline \multicolumn{2}{|c|}{$\mathrm{H}(2): \mathrm{a} 1=\mathrm{a} 2=\mathrm{a} 3=\mathrm{a} 4=0$} & & $\mathrm{~F}=1.8328$ & {$[0.1250]$} \\
\hline \multirow{2}{*}{\multicolumn{2}{|c|}{$\mathrm{H}(3): \mathrm{a} 0=\mathrm{a} 1=\mathrm{a} 2=\mathrm{a} 3=\mathrm{a} 4=0$}} & & $\mathrm{~F}=2.2409$ & {$[0.0528]$} \\
\hline & & $\mathrm{H}(4): \mathrm{a} 0=\mathrm{a} 1=\mathrm{a} 2=\mathrm{a} 3=\mathrm{a} 4=\mathrm{Ni} 15=0$ & $F=1.9667$ & {$[0.0734]$} \\
\hline
\end{tabular}

Standard errors in parentheses. Marginal significance levels in brackets. $\mathrm{Q}(12)$ and $\mathrm{Q}(24)$ are the Ljung-Box Q-statistics for lags 12 and 24.

Table 5. 3-month tin futures

\begin{tabular}{|c|c|c|c|c|}
\hline & Equation 2 & Equation 3 & Equation 4 & Equation 6 \\
\hline \multirow[t]{2}{*}{$\mathrm{a} 0$} & & 0.0119 & 0.0112 & 0.0117 \\
\hline & & $(0.0115)$ & $(0.0118)$ & $(0.0118)$ \\
\hline \multirow[t]{2}{*}{ al } & & & 0.1808 & 0.2218 \\
\hline & & & $(0.0816)$ & $(0.092)$ \\
\hline \multirow[t]{2}{*}{$\mathrm{a} 2$} & & & -0.0791 & -0.0632 \\
\hline & & & $(0.0822)$ & $(0.0822)$ \\
\hline \multirow[t]{2}{*}{ a3 } & & & -0.0402 & -0.0382 \\
\hline & & & $(0.0823)$ & $(0.0847)$ \\
\hline \multirow[t]{2}{*}{$\mathrm{a} 4$} & & & 0.1816 & 0.2226 \\
\hline & & & $(0.0814)$ & $(0.0902)$ \\
\hline \multirow[t]{2}{*}{ Sn15 } & & & & -0.0479 \\
\hline & & & & $(0.0468)$ \\
\hline \multirow[t]{2}{*}{$\mathrm{Q}(12)$} & 16.7940 & 16.8580 & 10.0980 & 11.6670 \\
\hline & {$[0.079]$} & {$[0.078]$} & {$[0.432]$} & {$[0.308]$} \\
\hline \multirow[t]{2}{*}{$\mathrm{Q}(24)$} & 27.8950 & 27.9680 & 21.1470 & 21.2410 \\
\hline & {$[0.179]$} & {$[0.177]$} & {$[0.512]$} & {$[0.506]$} \\
\hline $\mathrm{R}^{2}$ & 0.7342 & 0.7359 & 0.7466 & 0.7481 \\
\hline \multicolumn{2}{|c|}{$\mathrm{H}(1): \mathrm{a} 0=0$} & & $\mathrm{~F}=2.4342$ & {$[0.1207]$} \\
\hline \multicolumn{2}{|c|}{$\mathrm{H}(2): \mathrm{a} 1=\mathrm{a} 2=\mathrm{a} 3=\mathrm{a} 4=0$} & & $\mathrm{~F}=1.8328$ & {$[0.1250]$} \\
\hline \multicolumn{2}{|c|}{$\mathrm{H}(3): \mathrm{a} 0=\mathrm{a} 1=\mathrm{a} 2=\mathrm{a} 3=\mathrm{a} 4=0$} & & $\mathrm{~F}=2.2409$ & {$[0.0528]$} \\
\hline \multicolumn{3}{|c|}{$\mathrm{H}(4): \mathrm{a} 0=\mathrm{a} 1=\mathrm{a} 2=\mathrm{a} 3=\mathrm{a} 4=\mathrm{Ni} 15=0$} & $\mathrm{~F}=1.9667$ & {$[0.0734]$} \\
\hline
\end{tabular}

Table 4. 3-month lead futures

\begin{tabular}{|c|c|c|c|c|}
\hline & Equation 2 & Equation 3 & Equation 4 & Equation 6 \\
\hline \multirow[t]{2}{*}{$\mathrm{a} 0$} & & 0.0185 & 0.0188 & 0.0189 \\
\hline & & $(0.0137)$ & $(0.0143)$ & $(0.0144)$ \\
\hline \multirow[t]{2}{*}{ a1 } & & & 0.0967 & 0.1020 \\
\hline & & & $(0.0803)$ & $(0.0945)$ \\
\hline \multirow[t]{2}{*}{$\mathrm{a} 2$} & & & -0.1023 & -0.1007 \\
\hline & & & $(0.0797)$ & $(0.0814)$ \\
\hline \multirow[t]{2}{*}{ a3 } & & & 0.0733 & 0.0735 \\
\hline & & & $(0.0787)$ & $(0.079)$ \\
\hline \multirow[t]{2}{*}{ a4 } & & & 0.0674 & 0.0720 \\
\hline & & & $(0.0796)$ & $(0.0907)$ \\
\hline \multirow[t]{2}{*}{$\mathrm{Pb} 15$} & & & & -0.0054 \\
\hline & & & & $(0.0503)$ \\
\hline \multirow[t]{2}{*}{$\mathrm{Q}(12)$} & 13.9110 & 13.8720 & 10.5080 & 10.8370 \\
\hline & {$[0.177]$} & {$[0.179]$} & {$[0.397]$} & {$[0.370]$} \\
\hline \multirow[t]{2}{*}{$\mathrm{Q}(24)$} & 25.7440 & 25.7310 & 19.6360 & 20.1460 \\
\hline & {$[0.263]$} & {$[0.263]$} & {$[0.606]$} & {$[0.574]$} \\
\hline $\mathrm{R}^{2}$ & 0.7351 & 0.7380 & 0.7429 & 0.7429 \\
\hline \multicolumn{2}{|c|}{$H(1): a 0=0$} & & $\mathrm{~F}=1.7201$ & {$[0.1915]$} \\
\hline \multicolumn{2}{|c|}{$\mathrm{H}(2): \mathrm{a} 1=\mathrm{a} 2=\mathrm{a} 3=\mathrm{a} 4=0$} & & $\mathrm{~F}=1.2376$ & {$[0.2971]$} \\
\hline \multicolumn{2}{|c|}{$\mathrm{H}(3): \mathrm{a} 0=\mathrm{a} 1=\mathrm{a} 2=\mathrm{a} 3=\mathrm{a} 4=0$} & & $\mathrm{~F}=1.3662$ & [0.2397] \\
\hline $\mathrm{H}(4): \mathrm{a} 0=$ & $=\mathrm{a} 2=\mathrm{a} 3=\mathrm{a} 4=\mathrm{P}$ & $\mathrm{b} 15=0$ & $\mathrm{~F}=1.1335$ & {$[0.3453]$} \\
\hline
\end{tabular}

Table 6. 3-month zinc futures

\begin{tabular}{|c|c|c|c|c|}
\hline & Equation 2 & Equation 3 & Equation 4 & Equation 6 \\
\hline \multirow[t]{2}{*}{$\mathrm{a} 0$} & & 0.0050 & 0.0045 & 0.0466 \\
\hline & & $(0.0173)$ & $(0.0173)$ & $(0.0863)$ \\
\hline \multirow[t]{2}{*}{$\mathrm{a} 1$} & & & 0.0855 & -0.2215 \\
\hline & & & $(0.1365)$ & $(0.1133)$ \\
\hline \multirow[t]{2}{*}{$\mathrm{a} 2$} & & & 0.0943 & 0.0640 \\
\hline & & & $(0.1142)$ & $(0.0740)$ \\
\hline \multirow[t]{2}{*}{ a3 } & & & -0.0381 & -0.1160 \\
\hline & & & $(0.0939)$ & $(0.0742)$ \\
\hline \multirow[t]{2}{*}{$\mathrm{a} 4$} & & & 0.0786 & -0.0002 \\
\hline & & & $(0.1018)$ & $(0.0864)$ \\
\hline \multirow[t]{2}{*}{$\mathrm{Zn} 15$} & & & & -0.3654 \\
\hline & & & & $(0.1164)$ \\
\hline \multirow[t]{2}{*}{$\mathrm{Q}(12)$} & 16.8520 & 16.8320 & 11.0950 & 13.1470 \\
\hline & {$[0.051]$} & {$[0.051]$} & {$[0.269]$} & {$[0.156]$} \\
\hline \multirow[t]{2}{*}{$\mathrm{Q}(24)$} & 24.1270 & 24.0910 & 16.4890 & 19.9050 \\
\hline & {$[0.287]$} & {$[0.289]$} & {$[0.742]$} & {$[0.527]$} \\
\hline $\mathrm{R}^{2}$ & 0.7512 & 0.7513 & 0.7557 & 0.7620 \\
\hline \multicolumn{3}{|c|}{$H(1): a 0=0$} & $\mathrm{~F}=1.7201$ & {$[0.1915]$} \\
\hline \multicolumn{3}{|c|}{$\mathrm{H}(2): \mathrm{a} 1=\mathrm{a} 2=\mathrm{a} 3=\mathrm{a} 4=0$} & $\mathrm{~F}=1.2376$ & [0.2971] \\
\hline \multicolumn{3}{|c|}{$\mathrm{H}(3): \mathrm{a} 0=\mathrm{a} 1=\mathrm{a} 2=\mathrm{a} 3=\mathrm{a} 4=0$} & $\mathrm{~F}=1.3662$ & {$[0.2397]$} \\
\hline \multicolumn{3}{|c|}{$H(4): a 0=a 1=a 2=a 3=a 4=P b 15=0$} & $\mathrm{~F}=1.1335$ & {$[0.3453]$} \\
\hline
\end{tabular}


Table 7. 15-month aluminium futures

\begin{tabular}{|c|c|c|c|c|}
\hline & Equation 2 & Equation 3 & Equation 4 & Equation 6 \\
\hline \multirow[t]{2}{*}{$\mathrm{a} 0$} & & 0.0513 & 0.0457 & 0.0512 \\
\hline & & $(0.0459)$ & $(0.0463)$ & $(0.0439)$ \\
\hline \multirow[t]{2}{*}{ a1 } & & & 0.0516 & 0.1189 \\
\hline & & & $(0.0732)$ & $(0.0998)$ \\
\hline \multirow[t]{2}{*}{ a2 } & & & 0.0463 & 0.0177 \\
\hline & & & $(0.0751)$ & $(0.0761)$ \\
\hline \multirow[t]{2}{*}{$\mathrm{a} 3$} & & & 0.1017 & 0.0677 \\
\hline & & & $(0.0776)$ & $(0.0819)$ \\
\hline \multirow[t]{2}{*}{ a4 } & & & 0.1670 & 0.1026 \\
\hline & & & $(0.0719)$ & $(0.0999)$ \\
\hline \multirow[t]{2}{*}{$\mathrm{A} 13$} & & & & -0.1043 \\
\hline & & & & $(0.0796)$ \\
\hline \multirow[t]{2}{*}{$\mathrm{Q}(24)$} & 15.8550 & 17.6990 & 13.0960 & 12.74 \\
\hline & {$[0.104]$} & {$[0.0603]$} & {$[0.218]$} & {$[0.239]$} \\
\hline \multirow[t]{2}{*}{$\mathrm{Q}(48)$} & 41.2320 & 43.3620 & 32.6790 & 29.433 \\
\hline & {$[0.184]$} & {$[0.13]$} & {$[0.532]$} & {$[0.691]$} \\
\hline $\mathrm{R}^{2}$ & 0.9449 & 0.9482 & 0.9544 & 0.9533 \\
\hline \multicolumn{2}{|c|}{$\mathrm{H}(1): \mathrm{a} 0=0$} & $\mathrm{~F}=0.9765$ & {$[0.3248]$} & \\
\hline \multicolumn{2}{|c|}{$\mathrm{H}(2): \mathrm{a} 1=\mathrm{a} 2=\mathrm{a} 3=\mathrm{a} 4=0$} & $\mathrm{~F}=3.3274$ & {$[0.0123]$} & \\
\hline \multicolumn{2}{|c|}{$\mathrm{H}(3): \mathrm{a} 0=\mathrm{a} 1=\mathrm{a} 2=\mathrm{a} 3=\mathrm{a} 4=0$} & $\mathrm{~F}=4.4316$ & {$[0.0009]$} & \\
\hline \multicolumn{2}{|c|}{$\mathrm{H}(4): \mathrm{a} 0=\mathrm{a} 1=\mathrm{a} 2=\mathrm{a} 3=\mathrm{a} 4=\mathrm{A} 13=0$} & $\mathrm{~F}=4.2903$ & {$[0.0005]$} & \\
\hline
\end{tabular}

Table 8. 15-month copper futures

\begin{tabular}{|c|c|c|c|c|}
\hline & Equation 2 & Equation 3 & Equation 4 & Equation 6 \\
\hline \multirow[t]{2}{*}{$\mathrm{a} 0$} & & 0.1451 & 0.1126 & 0.2116 \\
\hline & & $(0.1065)$ & $(0.1164)$ & $(0.1777)$ \\
\hline \multirow[t]{2}{*}{ a1 } & & & -0.1093 & -0.2068 \\
\hline & & & $(0.0810)$ & $(0.0854)$ \\
\hline \multirow[t]{2}{*}{$\mathrm{a} 2$} & & & 0.1286 & 0.0630 \\
\hline & & & $(0.0793)$ & $(0.0741)$ \\
\hline \multirow{2}{*}{ a3 } & & & 0.0705 & 0.0565 \\
\hline & & & $(0.0812)$ & $(0.0738)$ \\
\hline \multirow[t]{2}{*}{$\mathrm{a} 4$} & & & -0.0142 & -0.1641 \\
\hline & & & $(0.0764)$ & $(0.0834)$ \\
\hline \multirow[t]{2}{*}{$\mathrm{Cu} 3$} & & & & -0.2424 \\
\hline & & & & $(0.0815)$ \\
\hline \multirow[t]{2}{*}{$\mathrm{Q}(24)$} & 9.8257 & 10.8210 & 9.7223 & 10.2050 \\
\hline & {$[0.365]$} & {$[0.288]$} & {$[0.373]$} & {$[0.334]$} \\
\hline \multirow[t]{2}{*}{$\mathrm{Q}(48)$} & 31.6250 & 32.4840 & 33.6840 & 32.6530 \\
\hline & {$[0.536]$} & {$[0.493]$} & {$[0.434]$} & {$[0.484]$} \\
\hline $\mathrm{R}^{2}$ & 0.9704 & 0.9710 & 0.9718 & 0.9728 \\
\hline \multicolumn{3}{|c|}{$\mathrm{H}(1): \mathrm{a} 0=0$} & $\mathrm{~F}=0.9352$ & {$[0.3352]$} \\
\hline \multicolumn{3}{|c|}{$\mathrm{H}(2): \mathrm{a} 1=\mathrm{a} 2=\mathrm{a} 3=\mathrm{a} 4=0$} & $\mathrm{~F}=1.4754$ & {$[0.2130]$} \\
\hline \multicolumn{3}{|c|}{$\mathrm{H}(3): \mathrm{a} 0=\mathrm{a} 1=\mathrm{a} 2=\mathrm{a} 3=\mathrm{a} 4=0$} & $\mathrm{~F}=1.3455$ & {$[0.2489]$} \\
\hline \multicolumn{3}{|c|}{$\mathrm{H}(4): \mathrm{a} 0=\mathrm{a} 1=\mathrm{a} 2=\mathrm{a} 3=\mathrm{a} 4=\mathrm{Cu} 3=0$} & $\mathrm{~F}=4.8221$ & {$[0.0002]$} \\
\hline
\end{tabular}

Standard errors in parentheses. Marginal significance levels in brackets.

Q(12), Q(24) and Q(48) are the Ljung-Box Q-statistics for lags 12, 24 and 48.

Table 9. 15-month nickel futures

\begin{tabular}{|c|c|c|c|c|}
\hline & Equation 2 & Equation 3 & Equation 4 & Equation 6 \\
\hline \multirow[t]{2}{*}{$\mathrm{a} 0$} & & 0.1507 & 0.2150 & 0.2493 \\
\hline & & $(0.1409)$ & $(0.1246)$ & $(0.1675)$ \\
\hline \multirow[t]{2}{*}{ a1 } & & & -0.1577 & -0.0833 \\
\hline & & & $(0.0842)$ & $(0.0957)$ \\
\hline \multirow[t]{2}{*}{$\mathrm{a} 2$} & & & -0.0957 & 0.0709 \\
\hline & & & $(0.0898)$ & $(0.0769)$ \\
\hline \multirow[t]{2}{*}{$\mathrm{a} 3$} & & & -0.0626 & -0.0263 \\
\hline & & & $(0.0882)$ & $(0.0813)$ \\
\hline \multirow[t]{2}{*}{$\mathrm{a} 4$} & & & 0.0373 & -0.3213 \\
\hline & & & $(0.0861)$ & $(0.1055)$ \\
\hline \multirow[t]{2}{*}{ Ni3 } & & & & -0.6000 \\
\hline & & & & $(0.1092)$ \\
\hline \multirow[t]{2}{*}{$\mathrm{Q}(24)$} & 8.9583 & 8.6532 & 7.0136 & 7.6356 \\
\hline & {$[0.536]$} & {$[0.565]$} & {$[0.724]$} & {$[0.664]$} \\
\hline \multirow[t]{2}{*}{$\mathrm{Q}(48)$} & 23.9580 & 23.5400 & 24.3450 & 27.7720 \\
\hline & {$[0.899]$} & [0.911] & [0.889] & {$[0.664]$} \\
\hline $\mathrm{R}^{2}$ & 0.9652 & 0.9654 & 0.9657 & 0.9655 \\
\hline \multicolumn{3}{|c|}{$\mathrm{H}(1): \mathrm{a} 0=0$} & $\mathrm{~F}=2.9756$ & {$[0.0868]$} \\
\hline \multicolumn{3}{|c|}{$\mathrm{H}(2): \mathrm{a} 1=\mathrm{a} 2=\mathrm{a} 3=\mathrm{a} 4=0$} & $\mathrm{~F}=1.4106$ & {$[0.2337]$} \\
\hline \multicolumn{3}{|c|}{$\mathrm{H}(3): \mathrm{a} 0=\mathrm{a} 1=\mathrm{a} 2=\mathrm{a} 3=\mathrm{a} 4=0$} & $\mathrm{~F}=1.2925$ & {$[0.2707]$} \\
\hline \multicolumn{3}{|c|}{$\mathrm{H}(4): \mathrm{a} 0=\mathrm{a} 1=\mathrm{a} 2=\mathrm{a} 3=\mathrm{a} 4=\mathrm{Ni} 3=0$} & $\mathrm{~F}=7.4019$ & {$[0.0000]$} \\
\hline
\end{tabular}

Table 10. 15-month lead futures

\begin{tabular}{|c|c|c|c|c|}
\hline & Equation 2 & Equation 3 & Equation 4 & Equation 6 \\
\hline \multirow[t]{2}{*}{$\mathrm{a} 0$} & & 0.2333 & 0.1387 & 0.1647 \\
\hline & & $(0.1031)$ & $(0.0554)$ & $(0.0782)$ \\
\hline \multirow[t]{2}{*}{ a1 } & & & 0.0575 & 0.1386 \\
\hline & & & $(0.0937)$ & $(0.1351)$ \\
\hline \multirow[t]{2}{*}{ a2 } & & & -0.1323 & -0.0429 \\
\hline & & & $(0.0795)$ & $(0.0880)$ \\
\hline \multirow[t]{2}{*}{ a3 } & & & 0.1059 & 0.082 \\
\hline & & & $(0.0879)$ & $(0.0951)$ \\
\hline \multirow[t]{2}{*}{$\mathrm{a} 4$} & & & 0.1903 & 0.1623 \\
\hline & & & $(0.0871)$ & $(0.1219)$ \\
\hline \multirow[t]{2}{*}{$\mathrm{Pb} 3$} & & & & -0.0106 \\
\hline & & & & $(0.1131)$ \\
\hline \multirow[t]{2}{*}{$\mathrm{Q}(24)$} & 14.0460 & 15.0371 & 17.2850 & 15.775 \\
\hline & {$[0.171]$} & {$[0.131]$} & [0.068] & [0.106] \\
\hline \multirow[t]{2}{*}{$\mathrm{Q}(48)$} & 35.0120 & 41.4990 & 35.2490 & 37.66 \\
\hline & {$[0.420]$} & {$[0.176]$} & [0.409] & {$[0.305]$} \\
\hline $\mathrm{R}^{2}$ & 0.9722 & 0.9732 & 0.9738 & 0.9733 \\
\hline \multicolumn{2}{|c|}{$\mathrm{H}(1): \mathrm{a} 0=0$} & & $\mathrm{~F}=6.2578$ & {$[0.0135]$} \\
\hline \multicolumn{2}{|c|}{$\mathrm{H}(2): \mathrm{a} 1=\mathrm{a} 2=\mathrm{a} 3=\mathrm{a} 4=0$} & & $\mathrm{~F}=2.2169$ & {$[0.0703]$} \\
\hline \multicolumn{2}{|c|}{$\mathrm{H}(3): \mathrm{a} 0=\mathrm{a} 1=\mathrm{a} 2=\mathrm{a} 3=\mathrm{a} 4=0$} & & $\mathrm{~F}=6.4294$ & {$[0.0000]$} \\
\hline \multicolumn{3}{|c|}{$\mathrm{H}(4): \mathrm{a} 0=\mathrm{a} 1=\mathrm{a} 2=\mathrm{a} 3=\mathrm{a} 4=\mathrm{Pb} 3=0$} & $\mathrm{~F}=2.1286$ & {$[0.0539]$} \\
\hline
\end{tabular}


Table 11. 15-month tin futures

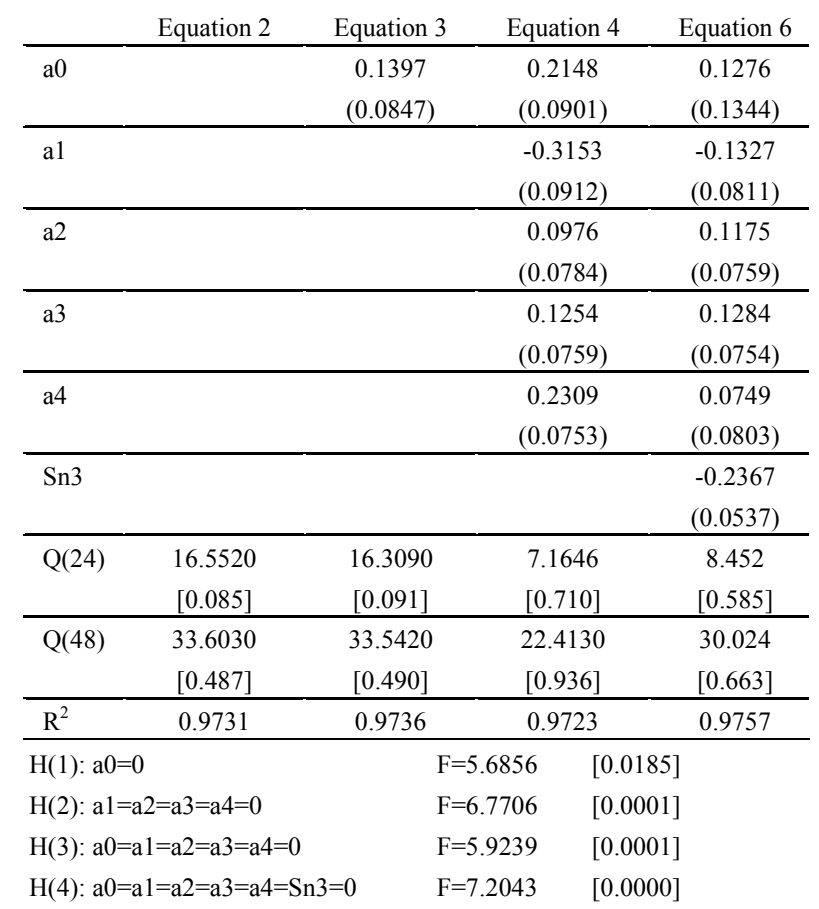

Standard errors in parentheses. Marginal significance levels in brackets.

$\mathrm{Q}(24)$ and Q(48) are the Ljung-Box Q-statistics for lags 24 and 48
Table 12. 15-month zinc futures

\begin{tabular}{|c|c|c|c|c|}
\hline & Equation 2 & Equation 3 & Equation 4 & Equation 6 \\
\hline \multirow[t]{2}{*}{$\mathrm{a} 0$} & & 0.0684 & 0.0299 & 0.0752 \\
\hline & & $(0.1181)$ & $(0.3319)$ & $(0.1663)$ \\
\hline \multirow[t]{2}{*}{ a1 } & & & -0.5163 & -0.4106 \\
\hline & & & $(0.0954)$ & $(0.1350)$ \\
\hline \multirow[t]{2}{*}{ a2 } & & & 0.0604 & 0.0362 \\
\hline & & & $(0.0986)$ & $(0.0865)$ \\
\hline \multirow[t]{2}{*}{ a3 } & & & -0.0495 & -0.0200 \\
\hline & & & $(0.0932)$ & $(0.0857)$ \\
\hline \multirow[t]{2}{*}{$\mathrm{a} 4$} & & & -0.1727 & 0.1511 \\
\hline & & & $(0.0917)$ & $(0.1177)$ \\
\hline \multirow[t]{2}{*}{$\mathrm{Zn} 3$} & & & & 0.1390 \\
\hline & & & & $(0.1212)$ \\
\hline \multirow[t]{2}{*}{$\mathrm{Q}(24)$} & 13.2010 & 13.0370 & 7.6362 & 6.6953 \\
\hline & {$[0.213]$} & {$[0.222]$} & {$[0.664]$} & {$[0.754]$} \\
\hline \multirow[t]{2}{*}{$\mathrm{Q}(48)$} & 24.6480 & 24.4060 & 21.5750 & 18.335 \\
\hline & {$[0.880]$} & {$[0.887]$} & {$[0.951]$} & {$[0.987]$} \\
\hline $\mathrm{R}^{2}$ & 0.9754 & 0.9754 & 0.9760 & 0.9769 \\
\hline \multicolumn{2}{|c|}{$\mathrm{H}(1): \mathrm{a} 0=0$} & \multicolumn{2}{|c|}{$\mathrm{F}=0.3350$} & {$[0.5637]$} \\
\hline \multicolumn{2}{|c|}{$\mathrm{H}(2): \mathrm{a} 1=\mathrm{a} 2=\mathrm{a} 3=\mathrm{a} 4=0$} & \multicolumn{2}{|c|}{$F=8.9144$} & {$[0.0000]$} \\
\hline \multicolumn{2}{|c|}{$\mathrm{H}(3): \mathrm{a} 0=\mathrm{a} 1=\mathrm{a} 2=\mathrm{a} 3=\mathrm{a} 4=0$} & \multicolumn{2}{|c|}{$F=7.1836$} & {$[0.0000]$} \\
\hline \multicolumn{2}{|c|}{$\mathrm{I}(4): \mathrm{a} 0=\mathrm{a} 1=\mathrm{a} 2=\mathrm{a} 3=\mathrm{a} 4=\mathrm{Zn}$} & & 328 & {$[0.0289]$} \\
\hline
\end{tabular}


Table 13. Multi-market

\begin{tabular}{|c|c|c|c|c|c|c|c|c|c|c|c|c|}
\hline & AL 3 & Al 15 & CU 3 & CU 15 & NI 3 & NI 15 & PB 3 & PB 15 & SN 3 & SN 15 & $\mathrm{ZN} 3$ & ZN 15 \\
\hline $\mathrm{a} 0$ & $\begin{array}{l}-0.001 \\
(0.011) \\
\end{array}$ & $\begin{array}{c}0.098 \\
(0.150) \\
\end{array}$ & $\begin{array}{c}0.014 \\
(0.015) \\
\end{array}$ & $\begin{array}{c}0.281 \\
(0.212) \\
\end{array}$ & $\begin{array}{c}0.035 \\
(0.020) \\
\end{array}$ & $\begin{array}{c}0.261 \\
(0.165) \\
\end{array}$ & $\begin{array}{c}0.012 \\
(0.015) \\
\end{array}$ & $\begin{array}{c}0.176 \\
(0.199) \\
\end{array}$ & $\begin{array}{c}0.009 \\
(0.012) \\
\end{array}$ & $\begin{array}{c}0.136 \\
(0.148) \\
\end{array}$ & $\begin{array}{c}0.026 \\
(0.069) \\
\end{array}$ & $\begin{array}{c}0.280 \\
(0.397) \\
\end{array}$ \\
\hline a1 & $\begin{array}{c}0.195 \\
(0.148)\end{array}$ & $\begin{array}{c}0.048 \\
(0.144)\end{array}$ & $\begin{array}{l}-0.031 \\
(0.121)\end{array}$ & $\begin{array}{l}-0.251 \\
(0.103)\end{array}$ & $\begin{array}{c}0.193 \\
(0.107)\end{array}$ & $\begin{array}{l}-0.147 \\
(0.126)\end{array}$ & $\begin{array}{c}0.213 \\
(0.113)\end{array}$ & $\begin{array}{l}-0.093 \\
(0.144)\end{array}$ & $\begin{array}{c}0.082 \\
(0.098)\end{array}$ & $\begin{array}{l}-0.125 \\
(0.110)\end{array}$ & $\begin{array}{l}-0.196 \\
(0.140)\end{array}$ & $\begin{array}{c}-0.252 \\
(0.170)\end{array}$ \\
\hline a2 & $\begin{array}{c}-0.011 \\
(0.094) \\
\end{array}$ & $\begin{array}{l}-0.095 \\
(0.085) \\
\end{array}$ & $\begin{array}{c}0.032 \\
(0.089) \\
\end{array}$ & $\begin{array}{c}0.039 \\
(0.074) \\
\end{array}$ & $\begin{array}{l}-0.040 \\
(0.082) \\
\end{array}$ & $\begin{array}{c}0.027 \\
(0.083) \\
\end{array}$ & $\begin{array}{l}-0.043 \\
(0.083) \\
\end{array}$ & $\begin{array}{c}0.105 \\
(0.086) \\
\end{array}$ & $\begin{array}{l}-0.006 \\
(0.076) \\
\end{array}$ & $\begin{array}{c}0.069 \\
(0.071) \\
\end{array}$ & $\begin{array}{c}0.087 \\
(0.079) \\
\end{array}$ & $\begin{array}{l}-0.047 \\
(0.084) \\
\end{array}$ \\
\hline a3 & $\begin{array}{c}0.058 \\
(0.091) \\
\end{array}$ & $\begin{array}{l}-0.090 \\
(0.083) \\
\end{array}$ & $\begin{array}{c}0.171 \\
(0.088) \\
\end{array}$ & $\begin{array}{c}0.038 \\
(0.074) \\
\end{array}$ & $\begin{array}{c}0.024 \\
(0.0810) \\
\end{array}$ & $\begin{array}{c}-0.071 \\
(0.081) \\
\end{array}$ & $\begin{array}{c}0.033 \\
(0.082) \\
\end{array}$ & $\begin{array}{c}-0.054 \\
(0.096) \\
\end{array}$ & $\begin{array}{c}0.007 \\
(0.078) \\
\end{array}$ & $\begin{array}{c}0.088 \\
(0.067) \\
\end{array}$ & $\begin{array}{c}-0.083 \\
(0.078) \\
\end{array}$ & $\begin{array}{l}-0.123 \\
(0.088) \\
\end{array}$ \\
\hline $\mathrm{a} 4$ & $\begin{array}{c}0.160 \\
(0.098) \\
\end{array}$ & $\begin{array}{c}-0.198 \\
(0.127) \\
\end{array}$ & $\begin{array}{c}0.113 \\
(0.098) \\
\end{array}$ & $\begin{array}{l}-0.216 \\
(0.090) \\
\end{array}$ & $\begin{array}{c}0.236 \\
(0.093) \\
\end{array}$ & $\begin{array}{l}-0.343 \\
(0.105) \\
\end{array}$ & $\begin{array}{c}0.125 \\
(0.094) \\
\end{array}$ & $\begin{array}{c}-0.099 \\
(0.116) \\
\end{array}$ & $\begin{array}{c}0.177 \\
(0.088) \\
\end{array}$ & $\begin{array}{c}-0.048 \\
(0.090) \\
\end{array}$ & $\begin{array}{c}-0.004 \\
(0.091) \\
\end{array}$ & $\begin{array}{c}-0.042 \\
(0.109) \\
\end{array}$ \\
\hline AL 3 & & $\begin{array}{l}-0.128 \\
(0.139) \\
\end{array}$ & $\begin{array}{c}0.189 \\
(0.137) \\
\end{array}$ & $\begin{array}{c}0.107 \\
(0.133) \\
\end{array}$ & $\begin{array}{c}0.107 \\
(0.175) \\
\end{array}$ & $\begin{array}{l}-0.106 \\
(0.217) \\
\end{array}$ & $\begin{array}{c}-0.158 \\
(0.133) \\
\end{array}$ & $\begin{array}{c}-0.081 \\
(0.131) \\
\end{array}$ & $\begin{array}{r}-0.080 \\
(0.116) \\
\end{array}$ & $\begin{array}{c}0.057 \\
(0.115) \\
\end{array}$ & $\begin{array}{l}-0.241 \\
(0.156) \\
\end{array}$ & $\begin{array}{c}0.361 \\
(0.140) \\
\end{array}$ \\
\hline AL 15 & $\begin{array}{c}-0.145 \\
(0.1134) \\
\end{array}$ & & $\begin{array}{r}-0.070 \\
(0.085) \\
\end{array}$ & $\begin{array}{r}-0.162 \\
(0.164) \\
\end{array}$ & $\begin{array}{c}-0.090 \\
(0.090) \\
\end{array}$ & $\begin{array}{c}0.121 \\
(0.239) \\
\end{array}$ & $\begin{array}{r}-0.114 \\
(0.072) \\
\end{array}$ & $\begin{array}{c}-0.114 \\
(0.145) \\
\end{array}$ & $\begin{array}{c}-0.005 \\
(0.079) \\
\end{array}$ & $\begin{array}{c}-0.058 \\
(0.128) \\
\end{array}$ & $\begin{array}{c}0.109 \\
(0.170) \\
\end{array}$ & $\begin{array}{r}-0.382 \\
(0.108) \\
\end{array}$ \\
\hline CU 3 & $\begin{array}{c}-0.078 \\
(0.096) \\
\end{array}$ & $\begin{array}{c}-0.076 \\
(0.080) \\
\end{array}$ & & $\begin{array}{c}-0.415 \\
(0.130) \\
\end{array}$ & $\begin{array}{c}-0.189 \\
(0.160) \\
\end{array}$ & $\begin{array}{l}-0.104 \\
(0.132) \\
\end{array}$ & $\begin{array}{c}0.187 \\
(0.121) \\
\end{array}$ & $\begin{array}{c}0.211 \\
(0.089) \\
\end{array}$ & $\begin{array}{c}-0.106 \\
(0.097) \\
\end{array}$ & $\begin{array}{c}-0.104 \\
(0.065) \\
\end{array}$ & $\begin{array}{c}-0.081 \\
(0.106) \\
\end{array}$ & $\begin{array}{c}-0.001 \\
(0.086) \\
\end{array}$ \\
\hline CU 15 & $\begin{array}{c}0.010 \\
(0.064) \\
\end{array}$ & $\begin{array}{l}-0.115 \\
(0.078) \\
\end{array}$ & $\begin{array}{c}0.004 \\
(0.061) \\
\end{array}$ & & $\begin{array}{c}0.069 \\
(0.072) \\
\end{array}$ & $\begin{array}{l}-0.184 \\
(0.145) \\
\end{array}$ & $\begin{array}{c}0.036 \\
(0.055) \\
\end{array}$ & $\begin{array}{c}-0.139 \\
(0.094) \\
\end{array}$ & $\begin{array}{c}-0.055 \\
(0.051) \\
\end{array}$ & $\begin{array}{c}-0.027 \\
(0.071) \\
\end{array}$ & $\begin{array}{c}0.173 \\
(0.095) \\
\end{array}$ & $\begin{array}{c}-0.201 \\
(0.076) \\
\end{array}$ \\
\hline NI 3 & $\begin{array}{c}-0.056 \\
(0.064) \\
\end{array}$ & $\begin{array}{c}-0.061 \\
(0.046) \\
\end{array}$ & $\begin{array}{c}0.001 \\
(0.080) \\
\end{array}$ & $\begin{array}{c}0.064 \\
(0.064) \\
\end{array}$ & & $\begin{array}{l}-0.439 \\
(0.118) \\
\end{array}$ & $\begin{array}{c}-0.019 \\
(0.080) \\
\end{array}$ & $\begin{array}{c}-0.096 \\
(0.052) \\
\end{array}$ & $\begin{array}{c}-0.053 \\
(0.066) \\
\end{array}$ & $\begin{array}{c}-0.198 \\
(0.054) \\
\end{array}$ & $\begin{array}{c}0.047 \\
(0.072) \\
\end{array}$ & $\begin{array}{l}-0.110 \\
(0.058) \\
\end{array}$ \\
\hline NI 15 & $\begin{array}{c}0.050 \\
(0.041) \\
\end{array}$ & $\begin{array}{c}0.034 \\
(0.047) \\
\end{array}$ & $\begin{array}{c}0.032 \\
(0.047) \\
\end{array}$ & $\begin{array}{c}-0.047 \\
(0.074) \\
\end{array}$ & $\begin{array}{c}-0.138 \\
(0.069) \\
\end{array}$ & & $\begin{array}{c}0.013 \\
(0.047) \\
\end{array}$ & $\begin{array}{c}-0.053 \\
(0.052) \\
\end{array}$ & $\begin{array}{c}0.085 \\
(0.037) \\
\end{array}$ & $\begin{array}{c}0.082 \\
(0.059) \\
\end{array}$ & $\begin{array}{c}-0.107 \\
(0.076) \\
\end{array}$ & $\begin{array}{c}0.064 \\
(0.056) \\
\end{array}$ \\
\hline PB 3 & $\begin{array}{c}0.112 \\
(0.088) \\
\end{array}$ & $\begin{array}{c}0.007 \\
(0.069) \\
\end{array}$ & $\begin{array}{l}-0.107 \\
(0.108) \\
\end{array}$ & $\begin{array}{l}-0.102 \\
(0.105) \\
\end{array}$ & $\begin{array}{l}-0.178 \\
(0.146) \\
\end{array}$ & $\begin{array}{l}-0.230 \\
(0.150) \\
\end{array}$ & & $\begin{array}{c}-0.315 \\
(0.119) \\
\end{array}$ & $\begin{array}{c}0.241 \\
(0.079) \\
\end{array}$ & $\begin{array}{c}0.078 \\
(0.088) \\
\end{array}$ & $\begin{array}{c}0.101 \\
(0.105) \\
\end{array}$ & $\begin{array}{c}0.141 \\
(0.102) \\
\end{array}$ \\
\hline PB 15 & $\begin{array}{c}0.058 \\
(0.060) \\
\end{array}$ & $\begin{array}{c}0.005 \\
(0.091) \\
\end{array}$ & $\begin{array}{c}0.141 \\
(0.066) \\
\end{array}$ & $\begin{array}{c}0.205 \\
(0.129) \\
\end{array}$ & $\begin{array}{c}0.034 \\
(0.089) \\
\end{array}$ & $\begin{array}{c}0.260 \\
(0.189) \\
\end{array}$ & $\begin{array}{c}-0.092 \\
(0.074) \\
\end{array}$ & & $\begin{array}{c}-0.029 \\
(0.054) \\
\end{array}$ & $\begin{array}{c}-0.025 \\
(0.097) \\
\end{array}$ & $\begin{array}{c}0.005 \\
(0.121) \\
\end{array}$ & $\begin{array}{c}-0.314 \\
(0.112) \\
\end{array}$ \\
\hline SN 3 & $\begin{array}{c}-0.033 \\
(0.097) \\
\end{array}$ & $\begin{array}{c}-0.169 \\
(0.070) \\
\end{array}$ & $\begin{array}{c}0.082 \\
(0.121) \\
\end{array}$ & $\begin{array}{c}-0.197 \\
(0.104) \\
\end{array}$ & $\begin{array}{c}0.266 \\
(0.162) \\
\end{array}$ & $\begin{array}{c}0.275 \\
(0.155) \\
\end{array}$ & $\begin{array}{c}-0.089 \\
(0.128) \\
\end{array}$ & $\begin{array}{c}-0.290 \\
(0.086) \\
\end{array}$ & & $\begin{array}{c}-0.251 \\
(0.122) \\
\end{array}$ & $\begin{array}{c}0.050 \\
(0.111) \\
\end{array}$ & $\begin{array}{l}-0.105 \\
(0.104) \\
\end{array}$ \\
\hline SN 15 & $\begin{array}{c}-0.114 \\
(0.062) \\
\end{array}$ & $\begin{array}{c}0.112 \\
(0.090) \\
\end{array}$ & $\begin{array}{r}-0.095 \\
(0.063) \\
\end{array}$ & $\begin{array}{c}0.121 \\
(0.107) \\
\end{array}$ & $\begin{array}{c}-0.026 \\
(0.078) \\
\end{array}$ & $\begin{array}{r}-0.238 \\
(0.180) \\
\end{array}$ & $\begin{array}{c}0.054 \\
(0.061) \\
\end{array}$ & $\begin{array}{c}0.244 \\
(0.105) \\
\end{array}$ & $\begin{array}{c}-0.118 \\
(0.059) \\
\end{array}$ & & $\begin{array}{c}-0.025 \\
(0.115) \\
\end{array}$ & $\begin{array}{c}0.284 \\
(0.084) \\
\end{array}$ \\
\hline $\mathrm{ZN} 3$ & $\begin{array}{c}-0.078 \\
(0.102) \\
\end{array}$ & $\begin{array}{c}0.087 \\
(0.078) \\
\end{array}$ & $\begin{array}{c}0.190 \\
(0.108) \\
\end{array}$ & $\begin{array}{c}0.113 \\
(0.116) \\
\end{array}$ & $\begin{array}{c}0.306 \\
(0.136) \\
\end{array}$ & $\begin{array}{l}-0.135 \\
(0.176) \\
\end{array}$ & $\begin{array}{l}-0.150 \\
(0.103) \\
\end{array}$ & $\begin{array}{c}-0.085 \\
(0.114) \\
\end{array}$ & $\begin{array}{c}0.163 \\
(0.089) \\
\end{array}$ & $\begin{array}{l}-0.031 \\
(0.102) \\
\end{array}$ & & $\begin{array}{c}-0.121 \\
(0.147) \\
\end{array}$ \\
\hline $\mathrm{ZN} 15$ & $\begin{array}{c}0.039 \\
(0.061) \\
\end{array}$ & $\begin{array}{l}-0.064 \\
(0.103) \\
\end{array}$ & $\begin{array}{l}-0.154 \\
(0.072) \\
\end{array}$ & $\begin{array}{l}-0.022 \\
(0.145) \\
\end{array}$ & $\begin{array}{c}0.031 \\
(0.091) \\
\end{array}$ & $\begin{array}{c}0.055 \\
(0.228) \\
\end{array}$ & $\begin{array}{c}0.078 \\
(0.068) \\
\end{array}$ & $\begin{array}{c}0.211 \\
(0.156) \\
\end{array}$ & $\begin{array}{c}0.074 \\
(0.060) \\
\end{array}$ & $\begin{array}{c}0.014 \\
(0.133) \\
\end{array}$ & $\begin{array}{c}-0.409 \\
(0.153) \\
\end{array}$ & \\
\hline $\mathrm{Q}(12 / 24)$ & $\begin{array}{c}8.723 \\
{[0.559]} \\
\end{array}$ & $\begin{array}{c}10.188 \\
{[0.424]} \\
\end{array}$ & $\begin{array}{l}12.222 \\
{[0.270]} \\
\end{array}$ & $\begin{array}{c}7.361 \\
{[0.691]} \\
\end{array}$ & $\begin{array}{c}12.392 \\
{[0.260]} \\
\end{array}$ & $\begin{array}{c}8.697 \\
{[0.561]} \\
\end{array}$ & $\begin{array}{c}7.707 \\
{[0.657]} \\
\end{array}$ & $\begin{array}{c}9.514 \\
{[0.484]} \\
\end{array}$ & $\begin{array}{c}9.418 \\
{[0.493]} \\
\end{array}$ & $\begin{array}{c}9.220 \\
{[0.511]} \\
\end{array}$ & $\begin{array}{l}11.286 \\
{[0.336]} \\
\end{array}$ & $\begin{array}{c}15.132 \\
{[0.127]} \\
\end{array}$ \\
\hline $\mathrm{Q}(24 / 48)$ & $\begin{array}{c}15.160 \\
{[0.855]}\end{array}$ & $\begin{array}{c}32.049 \\
{[0.564]}\end{array}$ & $\begin{array}{l}24.322 \\
{[0.331]}\end{array}$ & $\begin{array}{c}31.567 \\
{[0.587]}\end{array}$ & $\begin{array}{l}23.451 \\
{[0.377]}\end{array}$ & $\begin{array}{l}36.494 \\
{[0.354]}\end{array}$ & $\begin{array}{c}18.570 \\
{[0.672]} \\
\end{array}$ & $\begin{array}{l}31.950 \\
{[0.568]}\end{array}$ & $\begin{array}{l}23.800 \\
{[0.358]}\end{array}$ & $\begin{array}{l}25.165 \\
{[0.864]}\end{array}$ & $\begin{array}{l}20.804 \\
{[0.533]}\end{array}$ & $\begin{array}{l}28.572 \\
{[0.731]}\end{array}$ \\
\hline $\mathrm{R}^{2}$ & 0.686 & 0.959 & 0.804 & 0.975 & 0.777 & 0.968 & 0.765 & 0.976 & 0.799 & 0.980 & 0.777 & 0.980 \\
\hline$H(5):$ & $\begin{array}{c}0.835 \\
{[0.644]}\end{array}$ & $\begin{array}{c}3.494 \\
{[0.000]}\end{array}$ & $\begin{array}{c}1.661 \\
{[0.060]}\end{array}$ & $\begin{array}{c}3.199 \\
{[0.000]}\end{array}$ & $\begin{array}{c}3.171 \\
{[0.000]}\end{array}$ & $\begin{array}{c}2.198 \\
{[0.009]}\end{array}$ & $\begin{array}{c}1.831 \\
{[0.032]}\end{array}$ & $\begin{array}{c}5.199 \\
{[0.000]}\end{array}$ & $\begin{array}{c}3.702 \\
{[0.000]}\end{array}$ & $\begin{array}{c}15.847 \\
{[0.000]}\end{array}$ & $\begin{array}{c}3.044 \\
{[0.000]}\end{array}$ & $\begin{array}{c}9.103 \\
{[0.0000]}\end{array}$ \\
\hline
\end{tabular}

Standard errors in parentheses. Marginal significance levels in brackets.

$\mathrm{Q}(12)$ and Q(24) are the Ljung-Box Q-statistics for lags 12 and 24 (3-month-contarcts) and for lags 24 and 48 (15-months contracts). 
Table 14. Likelihood Ratio Tests

\begin{tabular}{|c|c|c|c|}
\hline & Single Contract & Multi Contract & $\begin{array}{c}\text { Multi Contract } \\
\text { Multi Market }\end{array}$ \\
\hline AL 3 & 3.4674 & 4.1618 & 14.2371 \\
\hline Prob.ChiSquare & {$[0.6283]$} & {$[0.6549]$} & {$[0.5811]$} \\
\hline AL15 & 4.1303 & 4.6241 & 19.0975 \\
\hline Prob.ChiSquare & {$[0.5308]$} & {$[0.5928]$} & {$[0.2636]$} \\
\hline $\mathrm{CU} 3$ & 12.0290 & 16.0537 & 26.9724 \\
\hline Prob.ChiSquare & {$[0.0344]$} & {$[0.0135]$} & {$[0.0418]$} \\
\hline CU 15 & 7.8469 & 13.5799 & 27.7643 \\
\hline Prob.ChiSquare & [0.1649] & {$[0.0347]$} & {$[0.0337]$} \\
\hline NI 3 & 10.3580 & 12.2407 & 27.4864 \\
\hline Prob.ChiSquare & {$[0.0657]$} & {$[0.0568]$} & {$[0.0364]$} \\
\hline NI 15 & 2.4550 & 29.3794 & 41.7869 \\
\hline Prob.ChiSquare & {$[0.7833]$} & {$[0.0001]$} & {$[0.0004]$} \\
\hline PB 3 & 6.7030 & 6.7152 & 21.8213 \\
\hline Prob.ChiSquare & {$[0.2437]$} & {$[0.3480]$} & {$[0.1491]$} \\
\hline PB 15 & 17.6178 & 12.0929 & 24.9717 \\
\hline Prob.ChiSquare & {$[0.0035]$} & {$[0.0599]$} & {$[0.0703]$} \\
\hline $\mathrm{SN} 3$ & 7.6216 & 8.5800 & 46.2949 \\
\hline Prob.ChiSquare & [0.1944] & [0.1986] & {$[0.0001]$} \\
\hline SN 15 & 13.7932 & 16.2758 & 37.2208 \\
\hline Prob.ChiSquare & {$[0.0170]$} & [0.0123] & {$[0.0020]$} \\
\hline $\mathrm{ZN} 3$ & 14.0753 & 18.4743 & 22.9969 \\
\hline Prob.ChiSquare & {$[0.0288]$} & {$[0.0052]$} & [0.1138] \\
\hline ZN 15 & 6.7113 & 15.3676 & 34.6597 \\
\hline Prob.ChiSquare & {$[0.2430]$} & {$[0.0089]$} & {$[0.0044]$} \\
\hline
\end{tabular}

Table 15. Winsorized data with cut-off points at the 1st and 99th percentile

\begin{tabular}{ccccccccccccc} 
& AL 3 & AL 15 & CU 3 & CU 15 & NI 3 & NI 15 & PB 3 & PB 15 & SN 3 & SN 15 & ZN 3 & ZN 15 \\
Wald Tests & & & & & & & & & & \\
\hline $\mathrm{H}(1)$ & 0.027 & 0.490 & 2.676 & 1.518 & 2.554 & 1.327 & 1.414 & 5.130 & 1.064 & 4.621 & 0.097 & 0.242 \\
& {$[0.870]$} & {$[0.485]$} & {$[0.103]$} & {$[0.220]$} & {$[0.112]$} & {$[0.251]$} & {$[0.236]$} & {$[0.025]$} & {$[0.304]$} & {$[0.033]$} & {$[0.756]$} & {$[0.624]$} \\
\hline $\mathrm{H}(2)$ & 1.113 & 3.907 & $\mathbf{5 . 8 6 0}$ & 1.665 & 2.043 & 1.768 & 1.172 & 1.916 & 3.815 & 3.766 & 11.966 & 9.024 \\
& {$[0.352]$} & {$[0.005]$} & {$[\mathbf{0 . 0 0 0}]$} & {$[0.162]$} & {$[0.091]$} & {$[0.139]$} & {$[0.325]$} & {$[0.112]$} & {$[0.005]$} & {$[0.006]$} & {$[0.000]$} & {$[0.000]$} \\
\hline $\mathrm{H}(3)$ & 0.902 & 5.221 & 5.272 & 1.546 & 2.246 & 0.175 & 1.314 & 2.418 & 3.266 & 4.011 & 9.623 & 7.269 \\
& {$[0.481]$} & {$[0.000]$} & {$[0.000]$} & {$[0.180]$} & {$[0.052]$} & {$[0.127]$} & {$[0.261]$} & {$[0.039]$} & {$[0.008]$} & {$[0.002]$} & {$[0.000]$} & {$[0.000]$} \\
\hline $\mathrm{H}(4)$ & 0.846 & 4.986 & 5.115 & 6.909 & $\mathbf{3 . 4 2 2}$ & 4.729 & 1.091 & 3.914 & 2.637 & 8.300 & 7.054 & 2.393 \\
& {$[0.536]$} & {$[0.000]$} & {$[0.000]$} & {$[0.000]$} & {$[\mathbf{0 . 0 0 3}]$} & {$[0.000]$} & {$[0.370]$} & {$[\mathbf{0 . 0 0 1}]$} & {$[0.018]$} & {$[0.000]$} & {$[0.000]$} & {$[0.031]$} \\
\hline $\mathrm{H}(5)$ & 0.784 & 2.286 & $\mathbf{3 . 3 2 8}$ & 1.894 & 2.494 & 5.940 & 4.364 & 5.392 & 5.724 & 22.180 & 3.141 & 12.109 \\
& {$[0.701]$} & {$[0.005]$} & {$[\mathbf{0 . 0 0 0}]$} & {$[0.025]$} & {$[0.002]$} & {$[0.000]$} & {$[0.000]$} & {$[0.000]$} & {$[0.000]$} & {$[0.000]$} & {$[0.000]$} & {$[0.000]$} \\
\hline Likelihood Ratio Tests & & & & & & & & & & \\
\hline $\mathrm{H}(3)$ & 4.193 & 7.178 & 21.243 & 7.316 & $\mathbf{1 2 . 5 7 5}$ & 5.376 & 6.571 & 12.324 & 7.553 & 15.698 & 14.557 & 6.133 \\
& {$[0.522]$} & {$[0.208]$} & {$[0.001]$} & {$[0.198]$} & {$[\mathbf{0 . 0 2 8}]$} & {$[0.372]$} & {$[0.255]$} & {$[0.031]$} & {$[0.183]$} & {$[0.008]$} & {$[0.012]$} & {$[0.294]$} \\
\hline $\mathrm{H}(4)$ & 4.688 & 7.297 & 26.675 & 23.339 & $\mathbf{1 4 . 3 0 2}$ & 22.503 & 6.587 & 11.570 & 8.551 & 17.781 & 21.505 & 16.462 \\
& {$[0.584]$} & {$[0.294]$} & {$[0.000]$} & {$[0.001]$} & {$[\mathbf{0 . 0 2 6}]$} & {$[0.001]$} & {$[0.361]$} & {$[0.072]$} & {$[0.128]$} & {$[0.022]$} & {$[0.002]$} & {$[0.012]$} \\
\hline $\mathrm{H}(5)$ & 13.566 & 21.847 & 44.454 & 26.541 & 26.536 & 29.074 & 23.057 & 25.809 & 51.870 & 35.595 & 23.550 & 31.847 \\
& {$[0.631]$} & {$[0.148]$} & {$[0.000]$} & {$[0.047]$} & {$[0.047]$} & {$[0.023]$} & {$[0.112]$} & {$[0.057]$} & {$[0.000]$} & {$[0.003]$} & {$[0.100]$} & {$[0.011]$} \\
\hline
\end{tabular}

Marginal significance levels in brackets. Bold letters indicate signifcant deviation from origianl data. 
Table 16. Subperiod Analysis

Panel 1: July 1991 - December 1999

\begin{tabular}{|c|c|c|c|c|c|c|c|c|c|c|c|c|}
\hline & AL 3 & AL 15 & $\mathrm{CU} 3$ & CU 15 & NI 3 & NI 15 & PB 3 & PB 15 & SN 3 & SN 15 & ZN 3 & ZN 15 \\
\hline \multirow[t]{2}{*}{$\mathrm{H}(1)$} & 0.107 & 0.103 & 0.001 & 0.026 & 0.001 & 0.034 & 0.975 & 0.545 & 0.118 & 1.785 & 0.791 & 0.387 \\
\hline & {$[0.744]$} & {$[0.750]$} & {$[0.974]$} & {$[0.873]$} & {$[0.977]$} & {$[0.854]$} & {$[0.326]$} & {$[0.463]$} & {$[0.732]$} & {$[0.186]$} & {$[0.377]$} & {$[0.536]$} \\
\hline \multirow[t]{2}{*}{$\mathrm{H}(2)$} & 1.501 & 1.439 & 1.496 & 2.633 & 48.520 & 2.125 & 1.524 & 3.908 & 3.051 & 6.301 & 0.336 & 5.832 \\
\hline & {$[0.208]$} & {$[0.232]$} & {$[0.212]$} & {$[0.043]$} & {$[0.000]$} & {$[0.090]$} & {$[0.204]$} & {$[0.008]$} & {$[0.022]$} & {$[0.000]$} & {$[0.853]$} & {$[0.001]$} \\
\hline \multirow[t]{2}{*}{$\mathrm{H}(3)$} & 1.186 & 0.915 & 2.752 & 1.942 & 48.567 & 1.897 & 1.222 & 6.190 & 3.207 & 4.923 & 0.313 & 4.876 \\
\hline & {$[0.324]$} & {$[0.478]$} & {$[0.025]$} & {$[0.101]$} & {$[0.000]$} & {$[0.110]$} & {$[0.307]$} & {$[0.000]$} & {$[0.011]$} & {$[0.001]$} & {$[0.903]$} & {$[0.001]$} \\
\hline \multirow[t]{2}{*}{$\mathrm{H}(4)$} & 1.009 & 1.604 & 3.635 & 4.550 & 1.052 & 9.514 & 1.324 & 1.882 & 2.190 & 6.322 & 1.479 & 2.487 \\
\hline & {$[0.426]$} & {$[0.163]$} & {$[0.003]$} & {$[0.001]$} & {$[0.399]$} & {$[0.000]$} & {$[0.258]$} & {$[0.100]$} & {$[0.053]$} & {$[0.000]$} & {$[0.198]$} & {$[0.031]$} \\
\hline \multirow[t]{2}{*}{$\mathrm{H}(5)$} & 1.360 & 28.815 & 1.215 & 5.821 & 1.648 & 11.294 & 2.804 & 4.037 & 3.167 & 11.176 & 1.401 & 4.951 \\
\hline & {$[0.188]$} & {$[0.000]$} & {$[0.280]$} & {$[0.000]$} & {$[0.082]$} & {$[0.000]$} & {$[0.002]$} & {$[0.000]$} & {$[0.001]$} & {$[0.000]$} & {$[0.167]$} & {$[0.000]$} \\
\hline \multicolumn{13}{|c|}{ Likelihood Ratio } \\
\hline \multirow[t]{2}{*}{$\mathrm{H}(3)$} & 4.933 & 3.481 & 4.743 & 5.858 & 4.777 & 6.010 & 5.277 & 13.183 & 9.212 & 26.690 & 5.783 & 1.711 \\
\hline & {$[0.424]$} & {$[0.626]$} & {$[0.448]$} & {$[0.320]$} & {$[0.444]$} & {$[0.305]$} & {$[0.383]$} & {$[0.022]$} & {$[0.101]$} & {$[0.000]$} & {$[0.328]$} & {$[0.888]$} \\
\hline \multirow[t]{2}{*}{$\mathrm{H}(4)$} & 6.686 & 4.320 & 7.488 & 35.438 & 6.728 & 42.701 & 8.404 & 7.667 & 11.553 & 38.690 & 18.462 & 10.208 \\
\hline & {$[0.351]$} & {$[0.504]$} & {$[0.278]$} & {$[0.000]$} & {$[0.347]$} & {$[0.000]$} & {$[0.210]$} & {$[0.176]$} & {$[0.073]$} & {$[0.000]$} & {$[0.005]$} & {$[0.070]$} \\
\hline \multirow[t]{2}{*}{$\mathrm{H}(5)$} & 13.004 & 19.005 & 25.652 & 19.124 & 28.766 & 34.895 & 23.401 & 25.257 & 45.231 & 42.760 & 22.546 & 34.259 \\
\hline & {$[0.673]$} & {$[0.268]$} & {$[0.059]$} & {$[0.262]$} & {$[0.026]$} & {$[0.004]$} & {$[0.103]$} & {$[0.065]$} & {$[0.000]$} & {$[0.000]$} & {$[0.126]$} & {$[0.005]$} \\
\hline \multicolumn{13}{|c|}{ Panel 2: January 2000 March 2008} \\
\hline & AL 3 & AL 15 & $\mathrm{CU} 3$ & $\mathrm{CU} 15$ & NI 3 & NI 15 & PB 3 & PB 15 & SN 3 & SN 15 & $\mathrm{ZN} 3$ & ZN 15 \\
\hline \multirow[t]{2}{*}{$\mathrm{H}(1)$} & 0.743 & 0.764 & 3.193 & 3.418 & 6.868 & 2.754 & 5.096 & 8.627 & 2.397 & 8.049 & 0.677 & 0.569 \\
\hline & {$[0.391]$} & {$[0.385]$} & {$[0.078]$} & {$[0.069]$} & {$[0.010]$} & {$[0.101]$} & {$[0.027]$} & {$[0.004]$} & {$[0.125]$} & {$[0.006]$} & {$[0.413]$} & {$[0.453]$} \\
\hline \multirow[t]{2}{*}{$\mathrm{H}(2)$} & 1.407 & 4.411 & 9.064 & 0.965 & 2.030 & 1.931 & 1.323 & 3.160 & 1.390 & 12.271 & 3.489 & 11.666 \\
\hline & {$[0.239]$} & {$[0.003]$} & {$[0.000]$} & {$[0.432]$} & {$[0.098]$} & {$[0.116]$} & {$[0.268]$} & {$[0.020]$} & {$[0.245]$} & {$[0.000]$} & {$[0.011]$} & {$[0.000]$} \\
\hline \multirow[t]{2}{*}{$\mathrm{H}(3)$} & 1.137 & 2.746 & 2.528 & 7.368 & 2.165 & 3.437 & 1.979 & 6.401 & 1.422 & 3.874 & 2.582 & 4.183 \\
\hline & {$[0.348]$} & {$[0.026]$} & {$[0.035]$} & {$[0.000]$} & {$[0.066]$} & {$[0.008]$} & {$[0.091]$} & {$[0.000]$} & {$[0.226]$} & {$[0.004]$} & {$[0.032]$} & {$[0.002]$} \\
\hline \multirow[t]{2}{*}{$\mathrm{H}(4)$} & 1.149 & 2.794 & 2.811 & 7.629 & 2.300 & 7.179 & 1.822 & 3.621 & 1.360 & 7.654 & 3.751 & 13.125 \\
\hline & {$[0.342]$} & {$[0.018]$} & {$[0.016]$} & {$[0.000]$} & {$[0.043]$} & {$[0.000]$} & {$[0.105]$} & {$[0.004]$} & {$[0.241]$} & {$[0.000]$} & {$[0.003]$} & {$[0.000]$} \\
\hline \multirow[t]{2}{*}{$\mathrm{H}(5)$} & 5.362 & 6.257 & 2.707 & 6.430 & 2.346 & 3.348 & 1.824 & 4.690 & 3.324 & 4.645 & 10.884 & 3.927 \\
\hline & {$[0.000]$} & {$[0.000]$} & {$[0.003]$} & {$[0.000]$} & {$[0.008]$} & {$[0.000]$} & {$[0.045]$} & {$[0.000]$} & {$[0.000]$} & {$[0.000]$} & {$[0.000]$} & {$[0.000]$} \\
\hline \multicolumn{13}{|c|}{ Likelihood Ratio } \\
\hline \multirow[t]{2}{*}{$\mathrm{H}(3)$} & 4.695 & 5.942 & 12.805 & 7.789 & 10.616 & 19.107 & 9.609 & 18.345 & 7.350 & 20.819 & 14.494 & 12.144 \\
\hline & {$[0.454]$} & {$[0.312]$} & {$[0.025]$} & {$[0.168]$} & {$[0.060]$} & {$[0.002]$} & {$[0.087]$} & {$[0.003]$} & {$[0.196]$} & {$[0.001]$} & {$[0.013]$} & {$[0.033]$} \\
\hline \multirow[t]{2}{*}{$\mathrm{H}(4)$} & 5.596 & 7.857 & 14.486 & 32.895 & 13.694 & 17.086 & 10.735 & 2.885 & 8.549 & 19.633 & 12.988 & 20.459 \\
\hline & {$[0.470]$} & {$[0.164]$} & {$[0.025]$} & {$[0.000]$} & {$[0.033]$} & {$[0.004]$} & {$[0.097]$} & {$[0.001]$} & {$[0.201]$} & {$[0.002]$} & {$[0.043]$} & {$[0.001]$} \\
\hline \multirow[t]{2}{*}{$\mathrm{H}(5)$} & 14.172 & 19.028 & 29.273 & 45.255 & 37.180 & 45.933 & 23.682 & 45.754 & 42.407 & 55.103 & 20.282 & 38.276 \\
\hline & {$[0.586]$} & {$[0.267]$} & {$[0.022]$} & {$[0.000]$} & {$[0.002]$} & {$[0.000]$} & {$[0.097]$} & {$[0.000]$} & {$[0.000]$} & {$[0.000]$} & {$[0.208]$} & {$[0.001]$} \\
\hline
\end{tabular}

Marginal significance levels in brackets. 